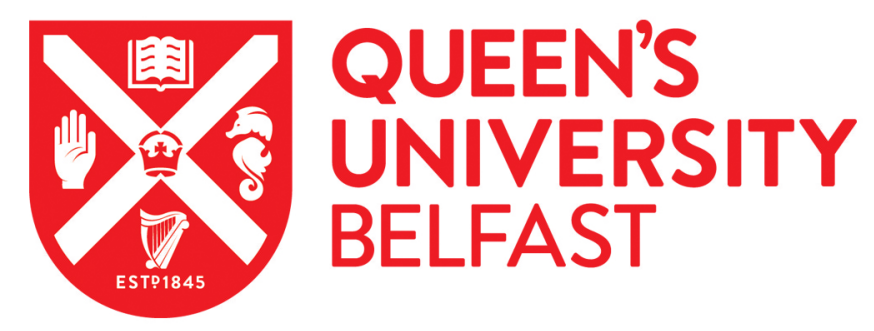

\title{
Walking the Street: No more motorways for Belfast
}

Martire, A. (2017). Walking the Street: No more motorways for Belfast. Spaces and Flows, 8(3), 35-61. https://doi.org/10.18848/2154-8676/CGP/v08i03/35-61

\author{
Published in: \\ Spaces and Flows
}

Document Version:

Publisher's PDF, also known as Version of record

Queen's University Belfast - Research Portal:

Link to publication record in Queen's University Belfast Research Portal

\section{Publisher rights}

Copyright 2018 the authors.

This is an open access article published under a Creative Commons Attribution-NonCommercial-NoDerivs License

(https://creativecommons.org/licenses/by-nc-nd/4.0/), which permits distribution and reproduction for non-commercial purposes, provided the author and source are cited.

\section{General rights}

Copyright for the publications made accessible via the Queen's University Belfast Research Portal is retained by the author(s) and / or other copyright owners and it is a condition of accessing these publications that users recognise and abide by the legal requirements associated with these rights.

\section{Take down policy}

The Research Portal is Queen's institutional repository that provides access to Queen's research output. Every effort has been made to ensure that content in the Research Portal does not infringe any person's rights, or applicable UK laws. If you discover content in the Research Portal that you believe breaches copyright or violates any law, please contact openaccess@qub.ac.uk. 


\section{Spaces and Flows:}

An International

Journal of Urban and

ExtraUrban Studies

Walking the Streets

No More Motorways for Belfast

AGUSTINA MARTIRE 
EDITOR

David Wilson, University of Illinois at Urbana-Champaign, USA

\section{MANAGING EDITOR}

Amanda Sabo, Common Ground Research Networks, USA

\section{ADVISORY BOARD}

Bill Cope, University of Illinois at Urbana-Champaign, USA

Ulrike Gerhard, Heidelberg University, Germany

Katherine Hankins, Georgia State University, USA

Andrew Jonas, University of Hull, UK

Phillip Kalantzis-Cope, The New School For Social Research, USA

Roger Keil, The City Institute at York University, Canada

Gordon MacLeod, Durham University, UK

Faranak Miraftab, University of Illinois at Urbana-Champaign, USA

Byron Miller, University of Calgary, Canada

Kevin Ward, University of Manchester, UK

Rachel Weber, University of Illinois at Chicago, USA

David Wilson, University of Illinois at Urbana-Champaign, USA

France Winddance Twine, University of California, USA

\section{PEER REVIEW}

Articles published in Spaces and Flows: An International Journal of Urban and ExtraUrban Studies are peer reviewed by scholars who are active participants of the Spaces \& Flows Research Network or a thematically related Research Network. Reviewers are acknowledged in the corresponding volume of the journal. For a full list, of past and current Reviewers please visit www.spacesandflows.com/journal/editors.

\author{
SPACES AND FLOWS: AN INTERNATIONAL JOURNAL \\ OF URBAN AND EXTRAURBAN STUDIES \\ http://spacesandflows.com \\ ISSN: 2154-8676 (Print) \\ ISSN: $2154-8684$ (Online) \\ http://doi.org/10.18848/2154-8676/CGP (Journal)
}

First published by Common Ground Research Networks in 2017

University of Illinois Research Park

2001 South First Street, Suite 202

Champaign, IL 61820 USA

$\mathrm{Ph}:+1-217-328-0405$

http://cgnetworks.org

Spaces and Flows: An International Journal of Urban and ExtraUrban Studies is a peer-reviewed, scholarly journal.

\section{COPYRIGHT}

C 2017 (individual papers), the author(s)

(C) 2017 (selection and editorial matter)

Common Ground Research Networks

\section{(ㅇ)(1) $\odot \odot$}

Some Rights Reserved.

Public Licensed Material: Available under the terms and conditions of the Creative Commons Attribution-NonCommercial-NoDerivatives 4.0 International Public License (CC BY-NC-ND 4.0). The use of this material is permitted for non-commercial use provided the creator(s) and publisher receive attribution. No derivatives of this version are permitted. Official terms of this public license apply as indicated here: https://creativecommons.org/licenses/by-nc-nd/4.0/legalcode

\section{Crossref}

Common Ground Research Networks, a member of Crossref

\section{ARTICLE SUBMISSION}

Spaces and Flows: An International Journal of Urban and ExtraUrban Studies publishes quarterly (March, June, September, December). To find out more about the submission process, please visit www.spacesandflows.com/journal/call-for-articles.

\section{ABSTRACTING AND INDEXING}

For a full list of databases in which this journal is indexed, please visit www.spacesandflows.com/journal.

\section{RESEARCH NETWORK MEMBERSHIP}

Authors in Spaces and Flows: An International Journal of Urban and ExtraUrban Studies are members of the Spaces \& Flows Research Network or a thematically related Research Network. Members receive access to journal content. To find out more, visit www.spacesandflows.com/about/become-a-member.

\section{SUBSCRIPTIONS}

Spaces and Flows: An International Journal of Urban and ExtraUrban Studies is available in electronic and print formats. Subscribe to gain access to content from the current year and the entire backlist. Contact us at support@ecgnetworks.org.

\section{ORDERING}

Single articles and issues are available from the journal bookstore at www.ijf.cgpublisher.com.

\section{HYBRID OPEN ACCESS}

Spaces and Flows: An International Journal of Urban and ExtraUrban Studies is Hybrid Open Access, meaning authors can choose to make their articles open access. This allows their work to reach an even wider audience, broadening the dissemination of their research. To find out more, please visit www.spacesandflows.com/journal/hybrid-open-access.

\section{DISCLAIMER}

The authors, editors, and publisher will not accept any legal responsibility for any errors or omissions that may have been made in this publication. The publisher makes no warranty, express or implied, with respect to the material contained herein. 


\title{
Walking the Streets: No More Motorways for Belfast
}

\author{
Agustina Martire, ${ }^{1}$ Queen’s University Belfast, UK
}

\begin{abstract}
This article explores how the spatial qualities and diversity of one of Belfast's main arteries, North Street/Peter's Hill, was transformed by urban planning decisions throughout the twentieth century. It looks specifically at how a car-dominated planning system contributed to the deterioration of the street fabric. Predicated on ideas of plotbased urbanism, the analysis of historic maps and plans points to the ways in which the function and dimensions of the buildings have contributed to the vibrancy of North Street/Peter's Hill and how the more recent transformation of those functions and dimensions damaged these streets. The article acknowledges that streets are made of the social and cultural context in which they exist, while their form and function is instrumental to their embedded public life.
\end{abstract}

Keywords: Streets, Motorways, Belfast, North Street, Pedestrians, Public Space

"More than a mere traffic channel ensconced within the city's solid mesh, the street is a complex civic institution, culture specific and capable of dazzling formal variation and calculated nuance" (Kostof 1992, 220).

\section{Introduction}

$\mathrm{S}$ treets are key elements of urban space; they are in essence public spaces and connect diverse areas of the city, weaving together the urban fabric. Streets can have the social, cultural, economic, and political layers of the city embodied in the buildings that bind them and the people that use them. However, urban planning and policy since the mid-twentieth century has neglected the importance of this complexity. Streets before the nineteenth century used to be the product of the organic evolution of the urban fabric. Large urban plans since the 1850s in Europe transformed the fabric of cities, but they did not change the tight connection between people and buildings and the multi-layered fabric of urban streets. On the other hand, since the 1950s, in a quest for improving growing urban centres throughout the world, transport planners transformed the fabric of cities. Once motorways replaced existing streets, they tore the urban fabric and transformed the qualities of the urban landscape. Zoning laws and redevelopment damaged the fabric of streets, broadening plots and separating the functions of buildings. In this context, streets were not given their deserved importance as public spaces. Growing scholarship since the 1960s defended and raised awareness of the value of streets as public spaces (Jacobs 1961; Whyte 1980; Rudofsky 1982; Burton and Mitchell 2006; Vernez Moudon 1987; Ford 2000; Southworth and Ben-Joseph 2003). Most urban designers agree about the qualities of good streets and describe them as accessible, permeable, lively, diverse, and public. Danish urban designer Jan Gehl $(2010,81)$ highlighted the importance of streets at eye level: "City streets with soft edges have a significant influence on activity patterns and the attractiveness of city space. The transparent, welcoming and active facades give city space a fine human scale just where it means most: up close and at eye level." This diversity at eye level can only be achieved by plot-based urbanism, where there is an "acknowledgment of the fundamental importance of the plot in the spatial structure of ordinary urban fabrics" and each plot is a "fenced portion of land that is entirely accessible from the public space" (Porta and Romice 2010, 14). This type of urban layout has been largely and broadly studied by urban morphology

\footnotetext{
${ }^{1}$ Corresponding Author: Agustina Martire, Architecture, School of Natural and Built Environment, Queens University Belfast, David Keir Building, Stranmillis Road, Belfast BT9 5AG, UK. email: a.martire@qub.ac.uk
}

Spaces and Flows: An International Journal of Urban and ExtraUrban Studies

Volume 8, Issue 3, 2017, www.spacesandflows.com

(C) Common Ground, Agustina Martire, Some Rights Reserved, (CC BY-NC-ND 4.0).

Permissions: support@cgnetworks.org

ISSN: 2154-8676 (Print), ISSN: 2154-8684 (Online)

https://doi.org/10.18848/2154-8676/CGP/v08i03/35-61 
(Conzen 1960; Whitehand 1987; Vance 1990). It covers the analysis of the evolution of urban form and also aims to understand the functional and social dimensions of urban evolution.

This paper will study North Street/Peter's Hill in Belfast (Figure 1) as an example of how the fabric of the street is transformed, while some of its original qualities are still preserved through the use of its buildings. It will analyse how planning and policy affected the functional diversity of the buildings, thus transforming the use of the street. By studying maps and plans of North Street/Peter's Hill throughout the twentieth century, the public use of the streets and their transformation can be better understood. Confronting these maps with observations by scholars from planning and urban history, this paper will evaluate the impact that planning decisionssuch as building roads and large retail units - had on the street studied. While not judging the value of public space in terms of user experience, this paper will attempt to understand this experience through the diversity and intensity of use, reflected in the maps and historic documents of the period studied.

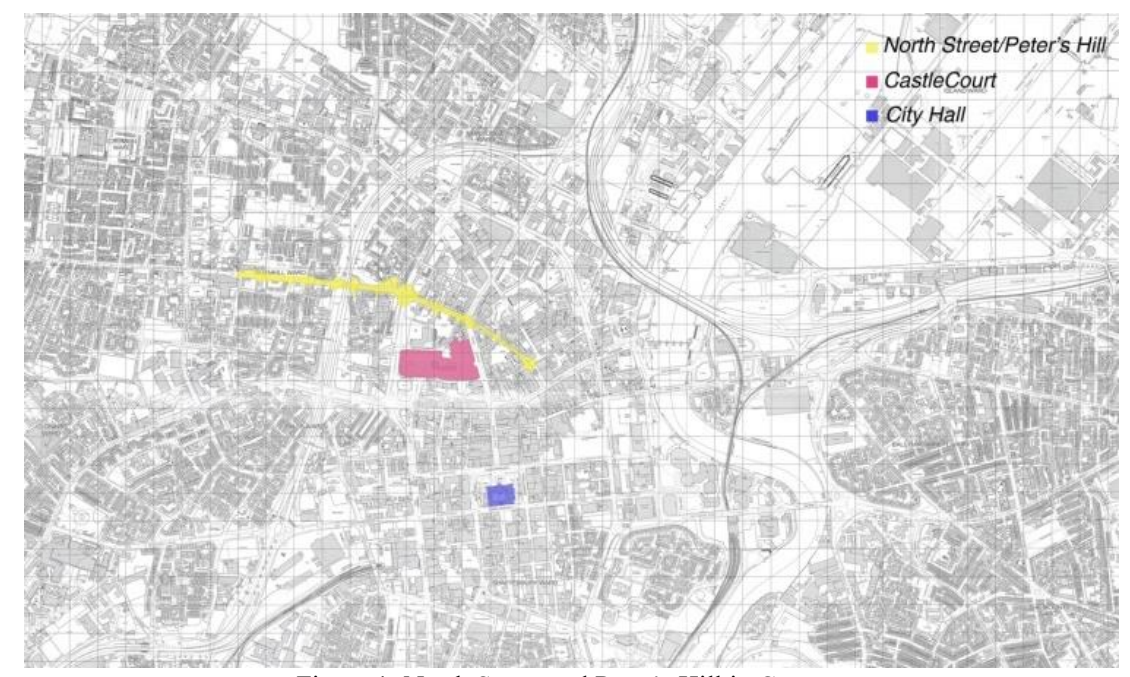

Figure 1: North Street and Peter's Hill in Context

Source: Belfast OS Map 2005; Ordnance Survey Northern Ireland 2005

\section{North Street/Peter's Hill in Context}

It is important to study North Street/Peter's Hill corridor for a number of reasons. Although North Street has a reputation for being run-down, derelict, and in need of redevelopment (Bridge 2010; Stewart 2014; BBC News 2015), it is one of the few streets in the Belfast City Centre where some of the original fabric of the street still exists, sustaining the trade of local and international population. As such, it is worthy of study as an example of public space that is not strictly commercial and franchised. North Street is threatened by imminent demolition as part of three different development plans for the area: Royal Exchange, Northside, and Northeast Quarter. These plans propose the demolition of many of the remaining buildings and businesses that sustain the diverse and vibrant atmosphere of North Street. Peter's Hill, on the other hand, was completely transformed in the 1970s from a traditionally multifunctional and vibrant street to a mono-functional residential area with few connections between the private and public realms and a difficult and spatially poor connection to the city centre. This is also the case of many other streets in the UK and Europe. It is important to highlight that North Street is the connection to the Protestant west and north Belfast, where the local population has been in constant decline throughout the last four decades. This is in contrast to the Castle Street corridor, a couple of hundred metres south, which connects the city centre with the Catholic west inner city. Catholic 
west Belfast has more successfully sustained its local population and its social, if not spatial, connection with the city centre. This paper will shed light on local processes in the past and present of Belfast. Figures 2 and 3 illustrate how the fabric of the street was completely transformed throughout the last fifty years, while alluding to the functional changes that this physical transformation implied.

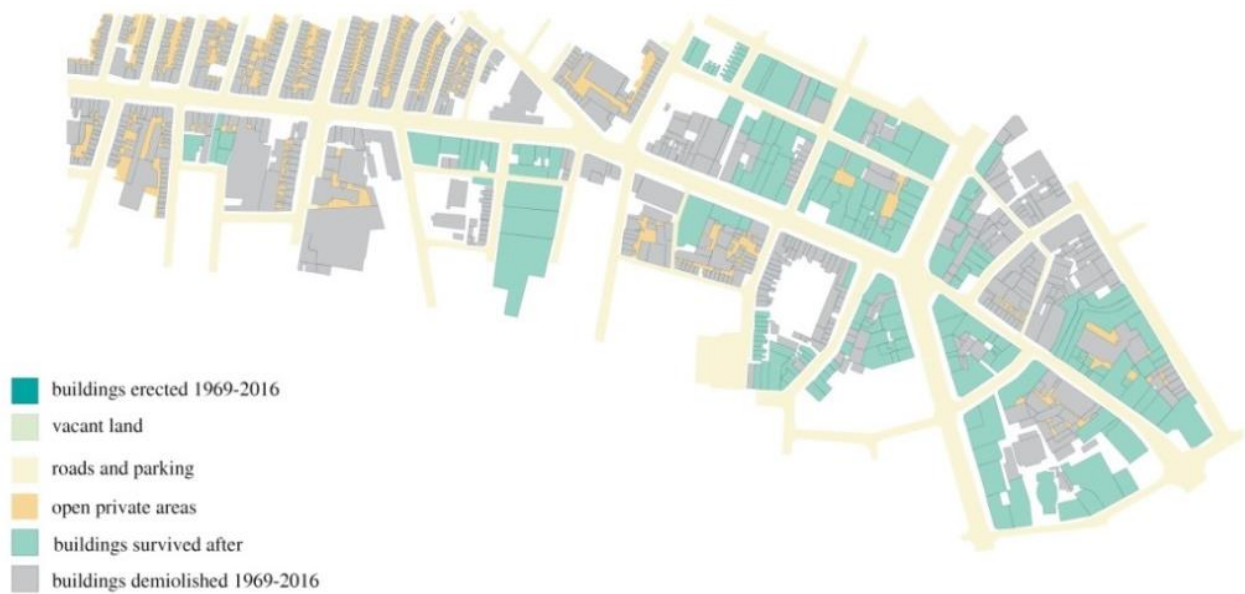

Figure 2: North Street and Peter's Hill in 1969

Source: Author: Agustina Martire; Base Map: OS Map; Ordnance Survey 1969

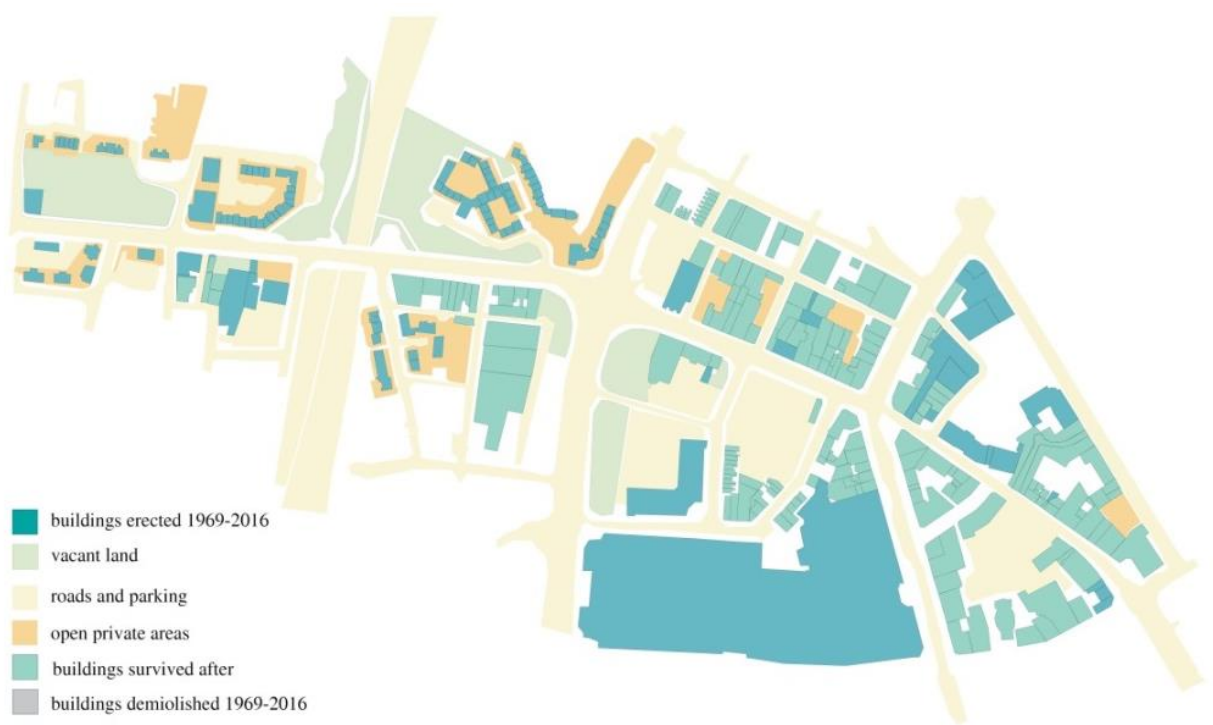

Figure 3: North Street and Peter's Hill in 2016

Source: Author: Agustina Martire; Base Map: OS Map; Ordnance Survey 2005; Google Maps 2016

The Regional Plan for Belfast was published in 1963 (Matthew 1963), followed by series of planning documents, including the Building Design Partnership Report of Belfast Corporation on Planning Policy in the City Centre in 1969. Among other issues, such as decentralisation and housing, the plans all proposed a ring road around Belfast that would radically transform the urban landscape, transforming the structure, fabric, mobility and social, and cultural and spatial reality of the city. As many other cities in post-war UK and around the world, Belfast was an experimental hub for new ideas about how cities should grow, develop, and function. Roads and 
transportation became a priority in the following decades, while streets as public spaces were relegated to the background. This process of urban transformation happened in the context of political turmoil in Northern Ireland known as "The Troubles." ${ }^{2}$ While the urban fabric of Belfast was indeed affected by "The Troubles" during the last three decades of the twentieth century, this was not the only cause of its transformation: The Blitz in the 1940s, the transport plans and "The Troubles" in the 1970s, suburbanisation in the 1980s, and large retail buildings since the 1990s all broke the spatial connections between the city centre and its surrounding neighbourhoods, leaving large areas of the city centre and adjacent spaces empty and derelict. Streets literally disappeared from the map or were transformed into larger blocks or buffer zones to divide the city centre and its peripheral areas. While scholarship (Boal and Douglas 1982; Bollens 2000; Ellis and McKay 2000; Murtagh 1999) has covered in depth the politics and policies of "The Troubles," in which issues of ethnic, political, and territorial segregation were salient factors, there is less research on the transformation of the formal, functional, and spatial qualities of the urban environment, especially streets, in that context. In fact, only a small number of academics and activists have highlighted this multifaceted process of urban segregation (Sterrett 2012; Gaffikin and Morrisey 2011; Murtagh 1999; Forum for Alternative Belfast 2009). Apart from these, there has been little attention on streets and their significance as public spaces in Belfast, especially in planning policy.

\section{Streets and Roads}

The value of streets as public spaces has been recognised in academia and urban design for decades (Jacobs 1961; Whyte 1980; Rudofsky 1982; Burton and Mitchell 2006; Vernez Moudon 1987; Ford 2000; Southworth and Ben-Joseph 2003; Mantho 2014) even though such trends are not always followed in practice. However, opinions on what constitutes value can vary. In academia, the tendency has been to raise awareness of the value of streets that are diverse, vibrant, and inclusive, yet urban policy has consistently focused on the commercial value of inner city streets, while urban design practice focuses on the formal and aesthetic principles that constitute a good street. Some commentators understand the value of streets beyond the positive ideas of liveability and vibrancy, addressing the importance of controlled negotiation and conflict on streets. Donald Appleyard mentioned in 1987 that "streets have always been scenes of conflict... Several competing population groups, establishments, public agencies, and professions vie with one another for control of the street space, each representing or claiming to be the public. The most powerful or well established groups win, but they do not by any means represent the public interest" (quoted in Vernez Moudon 1987, 5). The problem of streets as places of conflict is not exclusive to Belfast but constitutes a more general experience in diverse urban environments.

Urban streets until the nineteenth century were the product of the organic evolution of the urban fabric. The relatively slow growth of the city accommodated the different functions within the built environment, providing spaces for dwelling, trade, industry, and leisure. From the midnineteenth century, urban plans in European cities extended the fabric of towns into great metropoles or demolished and rebuilt whole areas of cities. The plans of Georges Eugene Haussmann for Paris, Ildefons Cerdá for Barcelona, and the Ringstrasse plan for Vienna are examples of different types of transformations to accommodate the growing population and transformation of city economies and functions. Even though these plans completely transformed the fabric of cities, they did not change the tight connection between people and buildings of plot-based urbanism and the multi-layered fabric of urban streets. Smaller cities in Europe saw a less radical growth and a slower adaptation to change. It was only in the twentieth century that transformation gained pace, precipitated by the advent of the motorcar. Globally, throughout the

\footnotetext{
${ }^{2}$ The Troubles was the ethno-nationalist conflict in Northern Ireland. The conflict began in the late 1960s and ended with the Belfast "Good Friday Agreement" of 1998.
} 
twentieth century, streets played a different role in the public life of cities and in the agendas of urban planning. Streets went from being the scenery of urban public life at the beginning of the century, to disappearing from the urban planning agenda after the wars, and back to the drawing boards by the end of the 1990s. As far back as the 1890s Camillo Sitte (Collins and Crasseman Collins 1986) pointed out that new road planning had no respect for existing structures, where large areas of cities and their street fabrics were demolished. Burnham and Bennett's (1909) Plan of Chicago considered transportation as critical for the development of their increasingly growing city. Despite developing the plan as an integrated system of roads and public transportation, the plan paved the way for car-centric urban systems central to twentieth century urban planning ideals. This conflict between private cars, public transport, and pedestrians has been present in the on-going transformation of streets throughout the twentieth century.

\section{North Street/Peter's Hill Urban History}

North Street was part of the first settlement of Belfast. In the Phillips map of 1685 (Figure 4), North Street already appears as a terraced street, divided into upper and lower sections by the city wall. This detailed map shows the street's narrow proportion and coherent residential plot division characteristic of its time. By 1789 North Street already appears as part of the corridor leading to the west through Shankill Road, consolidated, as the wall of the medieval town disappears.

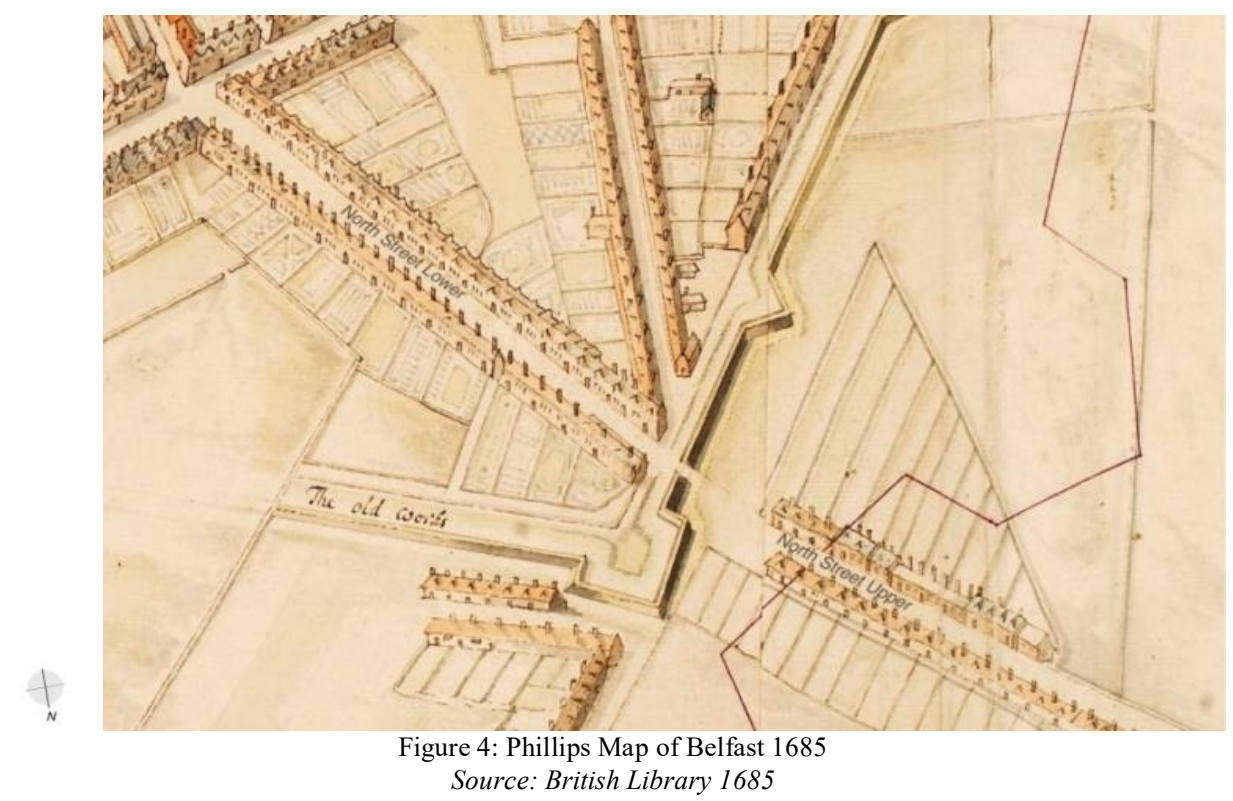

In the map of 1823 (Figure 5), North Street was already part of a more complex fabric of streets, with a series of multifunctional buildings, including the Assembly Rooms at the bottom of Lower North Street. Carrick Road appears as the division of North Street and Shankill, but the lower end of Shankill Road changed its name into Peter's Hill. The representation on the map of 1823 suggests a much denser construction behind the houses, which could be due to the changes of functions of the buildings from residential to semi-industrial or commercial. 


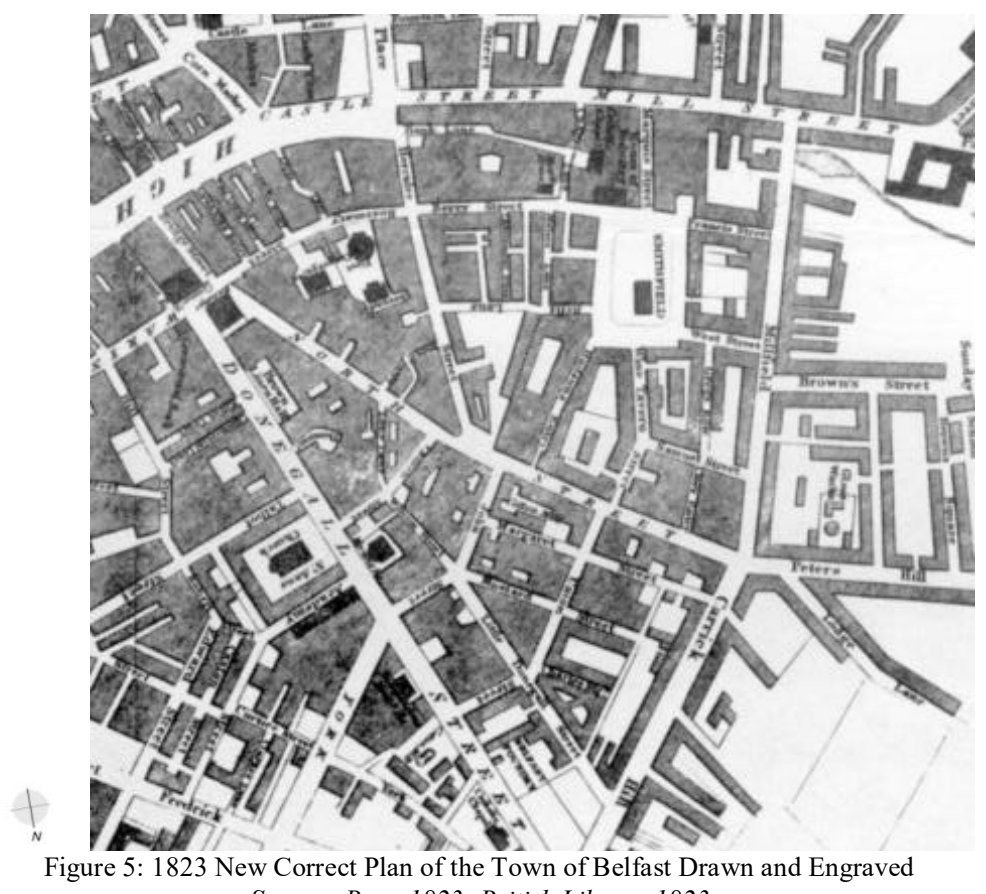

Source: Benn 1823; British Library 1823

Belfast was no exception to the development of urban space in the later nineteenth century. The city grew demographically and spatially due to the booming linen industry and the trade established by its production. According to Sean O'Connell, Belfast urban landscape "bears comparison to that of numerous industrial cities in Britain" (quoted in Connolly 2012, 571). The central area was a combination of administrative and industrial buildings woven into a fabric of commercial and residential buildings (Figure 6).

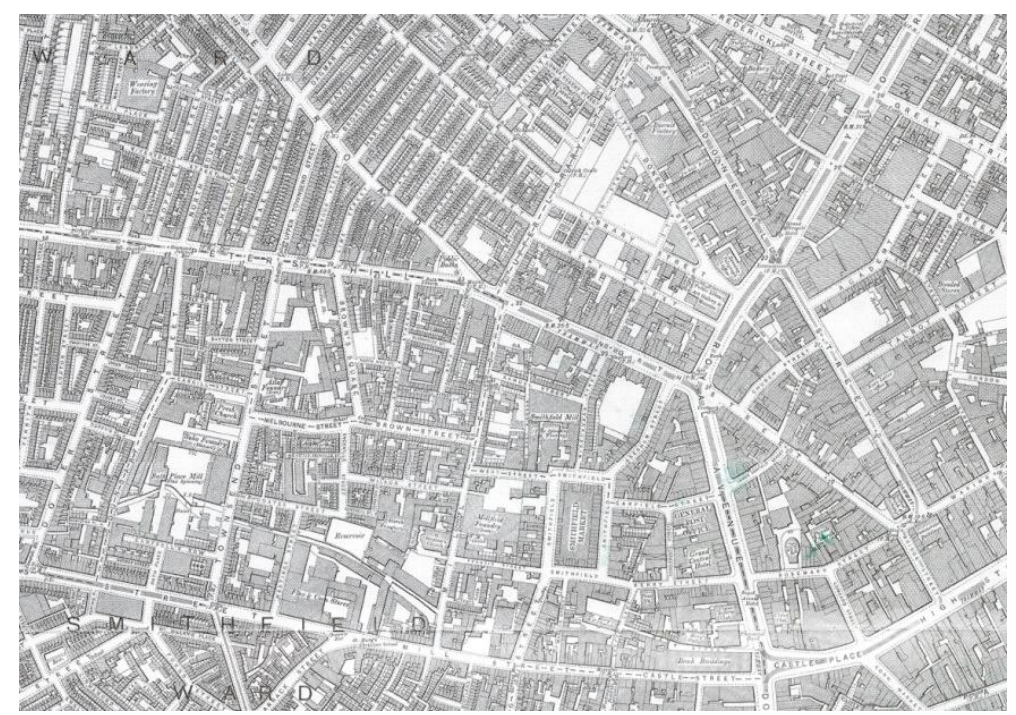

Figure 6: Belfast OS Map 1901—Note the Map Has the Correct North Orientation in 1901 Source: Ordnance Survey Northern Ireland 1901 
By 1901 Belfast was a well-established industrialised city called the "Workshop of the Empire" by Stephen Royle (Connolly 2012). West Belfast was developing as an industrial and residential area, and even though it was segregated, both Catholic and Protestant communities lived close to each other. The area defined by North Street and Peter's Hill was part of this tight urban fabric. Its length had a diverse population, from the more affluent area of North Street and Bridge Street to the vibrant combination of industry and working class housing of Peter's Hill and Shankill Road. North Street had by 1887 a total of 145 plots stretching 590 metres in length. Peter's Hill had 117 plots stretching more than 300 meters in length.

Suburban areas were growing steadily around Belfast, with direct connections to the centre through roads and public transport. Belfast was the centre for production and trade within Northern Ireland: "In 1935 Belfast employed in its factories $61 \%$ of the total manpower of Northern Ireland, and in 1951 the proportion was still 58\%, in spite of government efforts to promote the growth of light industries in the smaller towns of the province" (Evans and Jones 1955, 105).

By 1901 a tramway line running through Upper North Street and Peter's Hill was part of a wide network of public transport that connected the city centre with all the residential areas around it. In the early 1930s North Street had 139 plots, housing a vibrant mix of shops and services such as watchmakers, ladies and gents outfitters, hat and leather manufacturers, publicans, and theatres. In 1936 the building of North Street arcade enhanced the commercial character of the street, compensating for the few vacant buildings and sites on the street. Upper North Street was the access point to the Smithfield Market. Peter's Hill acted as a corridor between North Street and Shankill Road, and a backbone for a series of terraced houses on the northern face. The south face was lined with a combination of commercial and residential buildings, which acted as the front to plots of industrial areas. A series of baths, taverns, and public houses were also part of Peter's Hill in the last decades of the nineteenth century. The recession of the 1930s affected the economy of the city, but the urban landscape remained practically unchanged. It was not until World War II that the function, distribution, and form of the street started changing. The bombings of the 1941 caused some damage to the built fabric of North Street, especially on the southeast side (Figure 7). A total of four buildings were destroyed, comprising offices, stores, shops, and warerooms, while other buildings suffered damage. ${ }^{3}$

North Street continued to be a vibrant commercial street, and it quickly recovered from the destruction of the Blitz. By 1959 it only had four vacant buildings. During the following ten years the plots became bigger, with the closure of small individual shops and the opening of new larger retail units. By 1969 there were 100 units occupied, and only two were vacant.

\footnotetext{
${ }^{3}$ Information of these damaged properties has been obtained through insurance claims submitted after the bombings available in PRONI.
} 


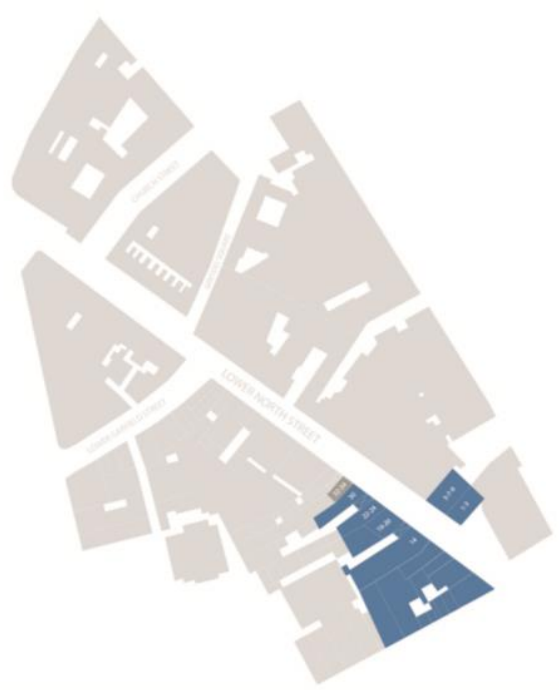

Figure 7: Buildings Destroyed and Partially Damaged by the Bombing of 1941 Based on Historic Maps and Street Directories Source: Campbell 2016

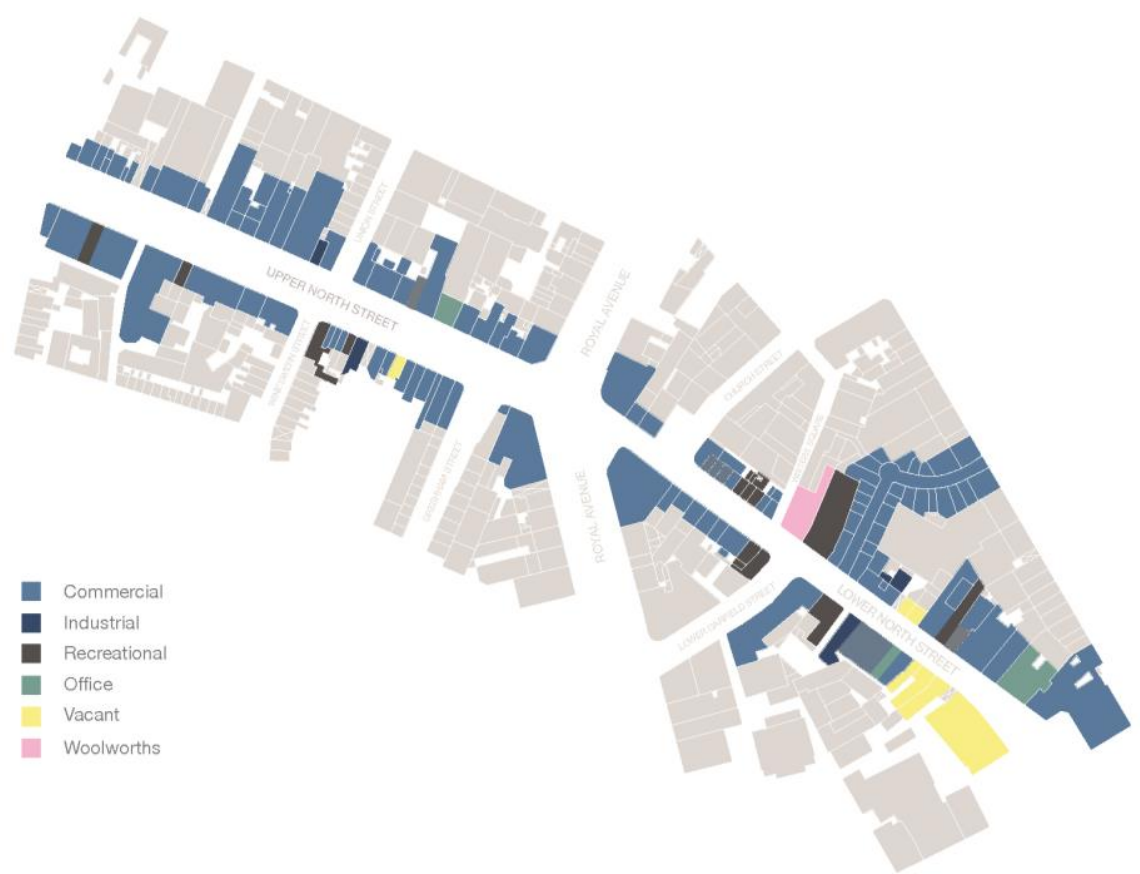

Figure 8: North Street 1959 Based on Historic Maps and Street Directories Source: Campbell 2016 


\section{Belfast Road Plans in Context}

The 1945 "Belfast Area Plan" (Figures 9 and 10) was produced by the Nanning Commission, made of experts appointed in 1942 with no public consultation. Specifically, the plan was focused on suburban growth, transport, industry, and "healthy and convenient residential areas" (Ellis, Murtagh, and Grounds 2015, 10). It was the first plan to propose three ring roads for Belfast and was specifically shown in two maps, a regional one and a map of Belfast City. Similarly, the 1952 Plan (Figures 11 and 12) proposed different versions of ring roads in and around Belfast. Plans proposed a physical intervention to widen roads; this was relatively minor compared to the plans that materialised a couple of decades later.

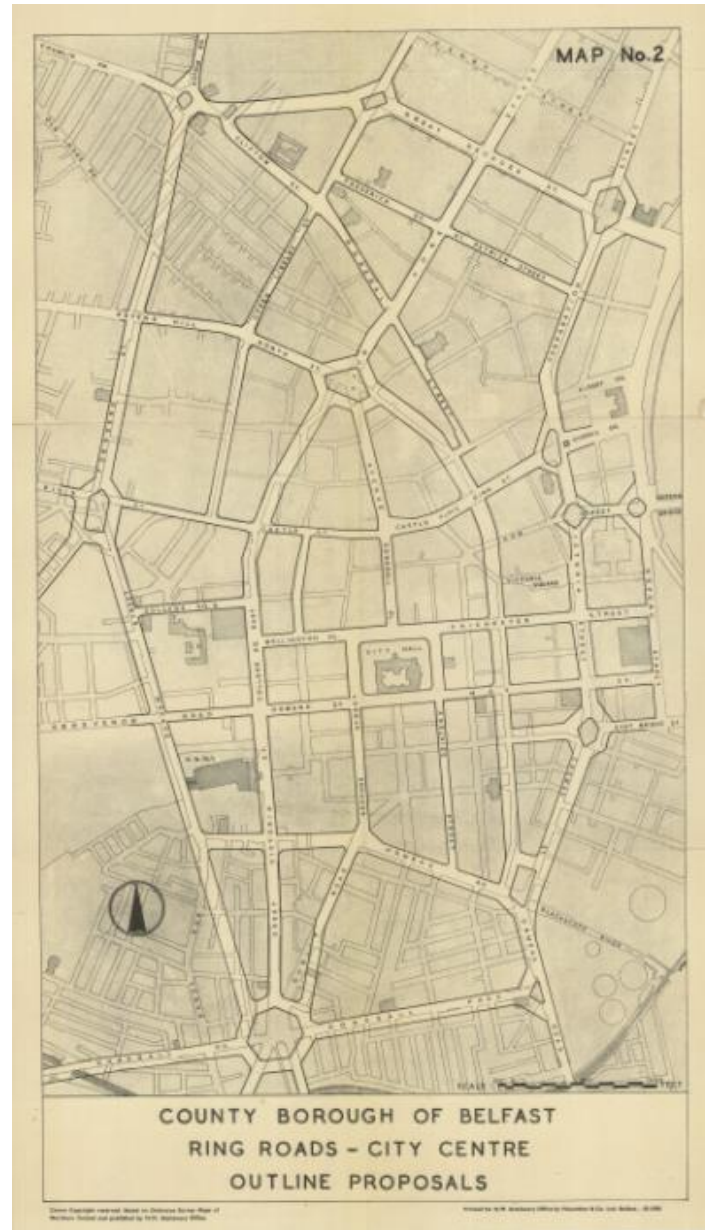

Figure 9: County Borough of Belfast Ring Roads (1945) — City Centre Outline Proposals (Published in 1952) Source: Queen's University Belfast Library Special Collections 1952 


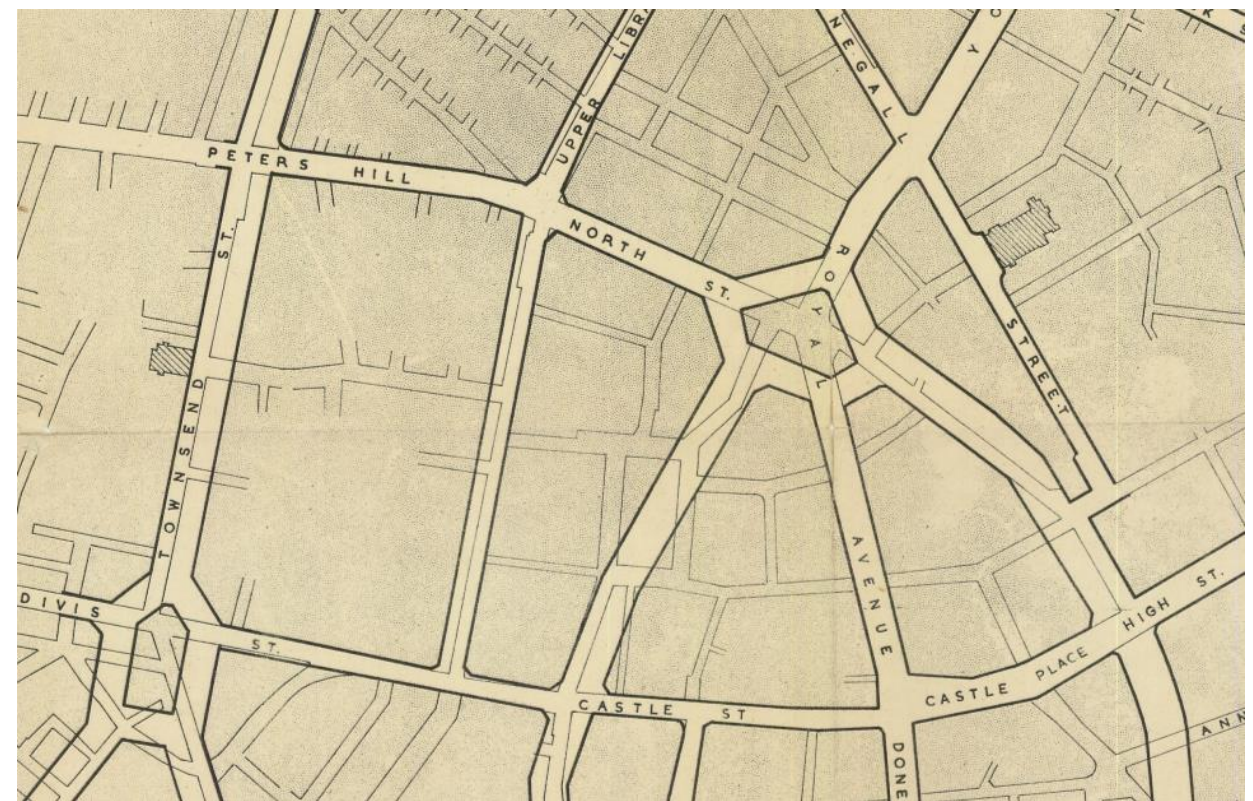

Figure 10: County Borough of Belfast Ring Roads (1945); City Centre Outline Proposals (Published in 1952) Source: Queen's University Belfast Library Special Collections 1952

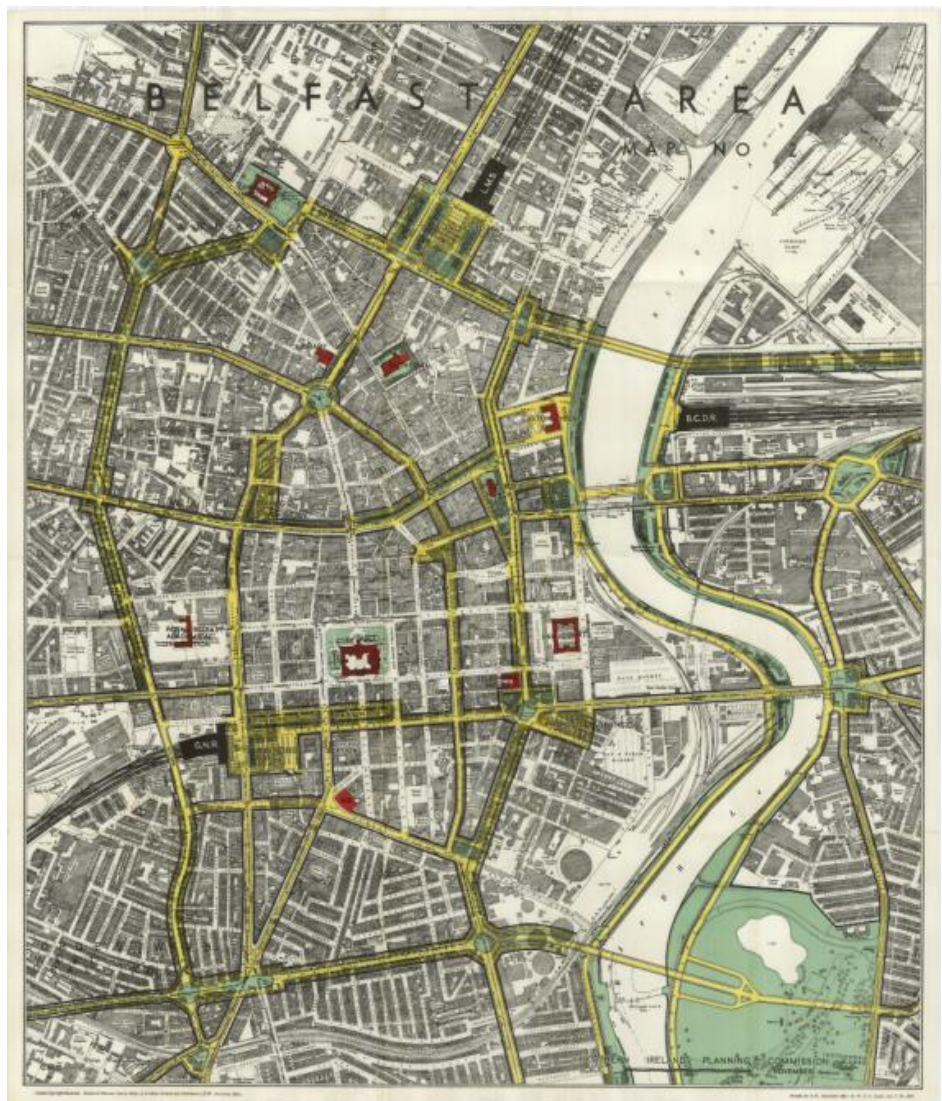

Figure 11: Proposal for Traffic and Transport in Central Belfast Area Map 02 (1952) Source: Queen's University Belfast Library Special Collections 1952 


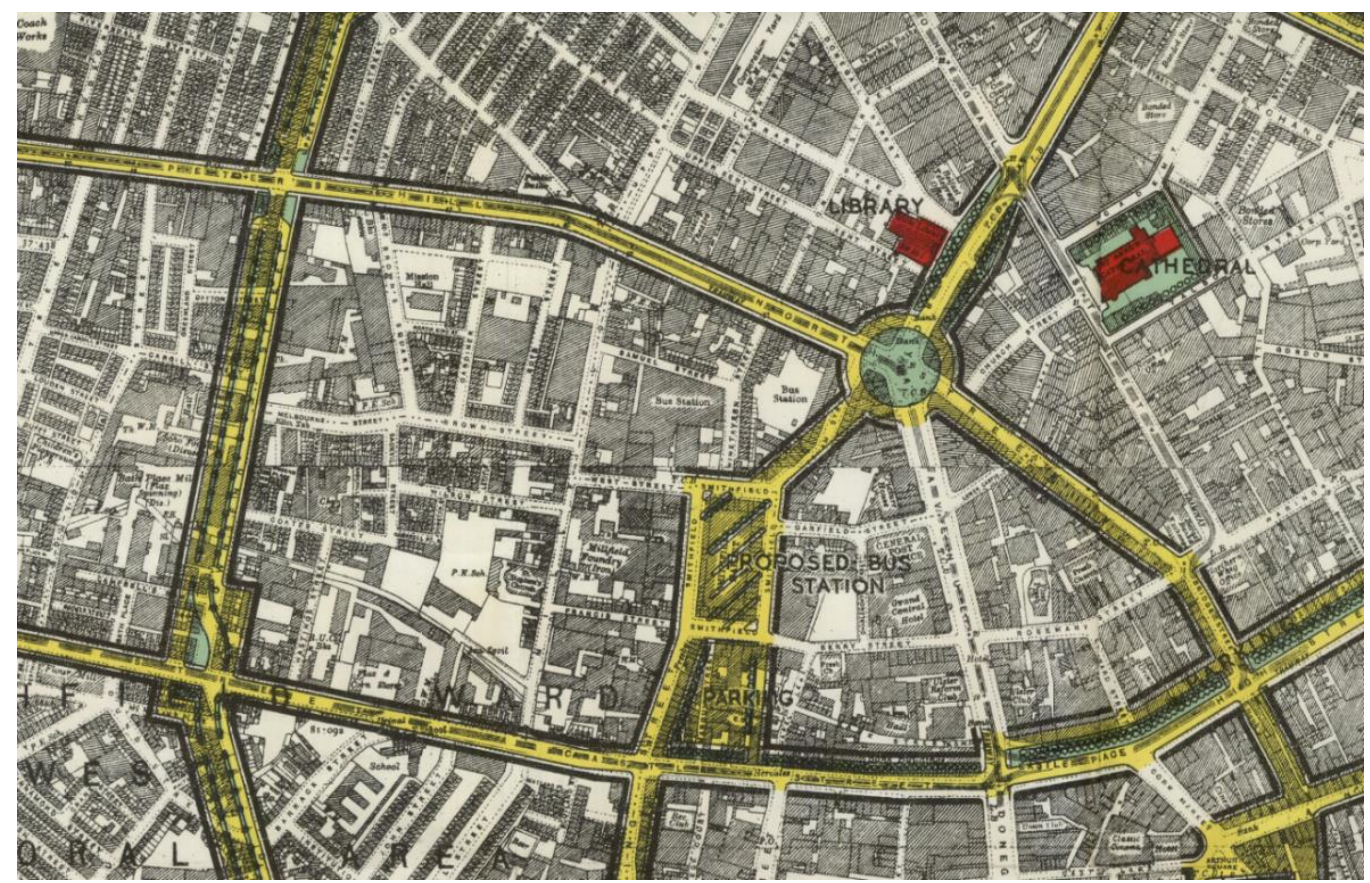

Figure 12: Proposal for Traffic and Transport in Central Belfast Area Map 02 (1952) Source: Queen's University Belfast Library Special Collections 1952

In both cases there is a roundabout between Upper and Lower North Street, while Peter's Hill remains virtually untouched. This set a precedent for the location of the current Westlink. There is in both plans an obvious proposal to widen Townsend Street, in the first case with a wide avenue and in the 1952 plan what seems to be a boulevard. On the other end, Bridge Street, closer to the centre, is partially demolished in both cases. However, there is a significant difference between the interventions of the plans of 1945 and 1952. In general the plan of 1945 seems more abstract and superimposes large blocks on the existing fabric, while the 1952 plan is more strategic about which building fronts are to disappear. The approach to North Street appears different in both plans. Upper North Street is largely demolished in the plan of 1945, to give way to the roundabout, while in the plan of 1952 the whole fabric of that section is respected and the tracing of the widened roads only reaches the frontages of the buildings. All corners of the junction of Royal Avenue and North Street disappear in both plans, which would have meant the demolition of buildings such as the Bank of Ireland and the Sinclair's department store, both now highly valued heritage buildings of the 1920s. For Lower North Street in the plan of 1945, the whole north side front is to be demolished to widen the street, with the exception of the Northern Bank building, while in the plan of 1952 the southern section is to be demolished. The 1952 plan obviously responded to the reality of the damage of the bombings, taking advantage of the vacant land on the south face of Lower North Street. In terms of transport, there was at the time a wellestablished public transport network on North Street with a tramway line heading west. The plans of 1945 and 1952 were not carried out, which meant that the fabric of the street we are studying was left untouched. However, these plans prepared the ground for the plans that would follow a couple of decades later. 
Belfast urban redevelopment was not unique. During the late 1940s and 50s many cities in the UK were redesigned based on principles of modernist urban design. ${ }^{4}$ Since the $1950 \mathrm{~s}$, in a quest for improving growing urban centres throughout the world, transport planners transformed the fabric of cities. Once motorways replaced existing streets, they tore the urban fabric and transformed the qualities of the urban landscape. In this context, streets were not given their deserved importance as public spaces, both in the writing of renowned urbanists and the early practice of urban design. Modernist architects and urban planners prioritised efficiency of transport and the compartmentalisation of life, designing public spaces separated from the built fabric. Le Corbusier (1929) stated repeatedly in The City of Tomorrow that straight streets should only be used for cars and winding streets only for pedestrians. These are not really streets, but roads, exclusively meant for transport. Road-oriented planning grew internationally, and by the 1960s most cities in the world were developing broad tabula rasa transport infrastructure. Cities that had slowly adapted to change were suddenly confronted with major infrastructural transformations. These developments respond to the ideas of urban morphologists like James Vance $(1990,22)$ who stated that "physical adaptation comes about when the functional demands outreach the tolerance of the form to deal with that change." The form of narrow streets did not accommodate the planned function of the city at that time, so the change was imminent.

In the UK, this new approach to urban planning was embodied in the Buchanan Report. The Report responded to the growing problem of traffic in Great Britain (Buchanan 1963). This was the first attempt in the UK to address the growing population and its transforming mobility as collaboration between architects, planners, and engineers, not focussing on specific areas but as a general national approach to transport planning. The report highlighted the obvious problems of the growth of car ownership and the current and possible effect on the growth of cities. It highlighted the approach to the "crucial point when the ownership of motor vehicles, instead of being the privilege of a minority, becomes the expectation of a majority" (Buchanan 1963, 6). The Buchanan report outlined the difficulties of the rising use of vehicles in cities that were not designed for their speed and volume. The study considers issues of safety, noise, fumes, and smells. It speculates on the growth of the motor vehicle and it does indeed consider/evaluate the form of urban areas and the difficulties this form poses to the development of a new transport infrastructure. The study essentially focuses on the efficient and coherent distribution of traffic in towns and cities, providing schemes of networks and considering the cost as a crucial variable when determining the quality of the required physical transformations. The study differentiates itself from previous research by not primarily focusing on "keeping vehicles on the move" (Buchanan 1963, 52), but on an inward-outward progression. Even though this study may have been more socially inclusive, it still promoted the growth of car transportation and the forced division of function in cities, which many municipalities are now confronting and transforming. In terms of residential areas, it is interesting to see the development of the "Radburn Layout," a system made of pedestrian superblocks with the fronts of some houses facing the street and others the pedestrian area. This cul-de-sac model was adopted repeatedly in Belfast, but has been largely criticised in recent years (Lucy and Phillips 2006; Bajunid et al. 2013; Cozens and Hillier 2008; Hochschild 2014).

\section{Belfast Motorway Plans}

Belfast was no exception to the mentioned urban transformations. The need for immediate housing supply and a broad road network to cater to the new suburban development became the government's top agenda. According to Fredrick Boal (1994), planning in Belfast between the end of World War II and the late 1960s was dominated by three basic themes: the growth of population in Belfast, the physical spread of the city, and the poor housing conditions in inner

\footnotetext{
${ }^{4}$ We understand modernist urban design as that established in the Athens Charter in 1933 and adopted by innumerable architects, planners, and engineers during the twentieth century.
} 
Belfast. The Regional Plan for Belfast (Figure 13) was published in 1963 and its prime objective was "to simultaneously demagnetise the centre, and re-invigorate the many attractive small towns in the Region" (Boal 1994, 37). This was evidently a plan focused on zoning policies that would encourage people to leave the city core and populate the outskirts, leaving only commercial and administrative functions in the city centre. The aims of the 1967 version of the Plan were to "ensure the continuous availability of sufficient land for private and public housing and associated uses, industry and commerce within the stop-line and growth centres" (Building Design Partnership 1967, 12). The partnership assumed that 3500 families residing in the area would be affected by the urban motorway, but this fact was not considered as a great disruption at the time. The planning objectives of the document highlighted the need to ensure safe and acceptable pedestrian conditions and to improve the attractiveness of public transport. It also stated that parking facilities, adequate motorway, and main access should be provided for the city centre and the harbour. Unfortunately, in practice, only parking and motorways were catered for, ignoring pedestrians and public transport. The 1969 Report on Belfast Corporation gave accurate details about the plans for the city centre. It stated: "A road based transport system was selected by the Transportation Consultants after an examination of the feasibility and benefit of developing a rapid transit system" (Building Design Partnership 1969, 8).

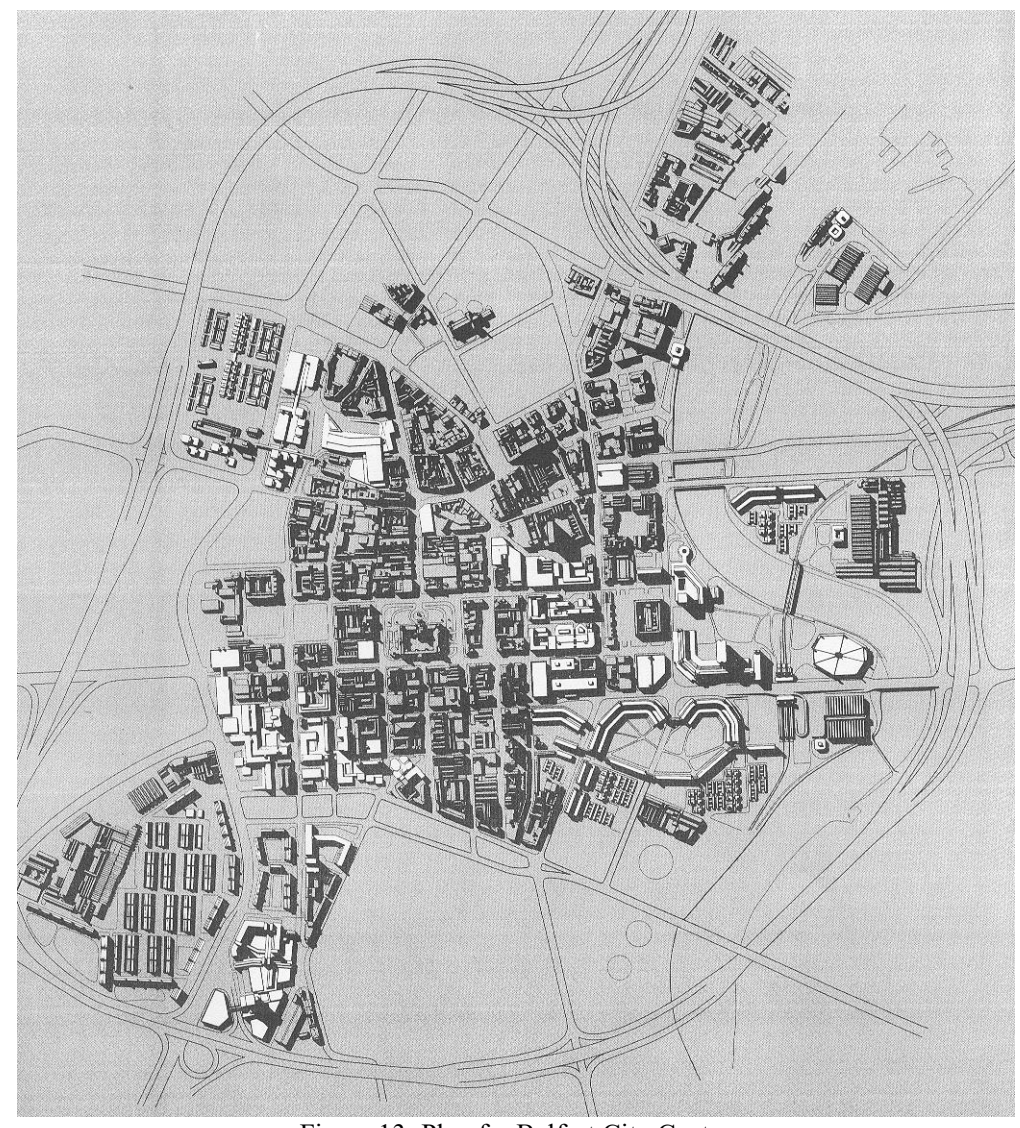

Figure 13: Plan for Belfast City Centre

Source: Building Design Partnership 1969; Queen's University Belfast Library 1969

The maps in the report show a land zoning scheme that concentrated shopping in the city core, offices and commerce in a second ring around the shopping area, housing and commerce in the third ring, industry in the north, and markets in the east. This scheme forced the limited 
functions of the city in the following decades and the relocation of residential areas outside of the city core. The 1967 and 1969 plans included the development of a high rise motorway surrounding the city centre. The uses of the spaces under the motorway were explicitly drawn (Figure 14). Those people under the road, whether it is in an office, a boat or a park have no sense of the noise and pollution happening just metres away from them. According to Ron Weiner $(1976,140)$ the effects of the motorway project went beyond the formal transformation of the city, changing its functions and affecting the social fabric that had been long established in the inner city: "With redevelopment the number of social and economic units were greatly reduced...It was recognised that the loss of shops would be to the detriment of communal life." The high-rise motorway was not built. Instead a system of roundabouts was designed for most of the roads surrounding the city.
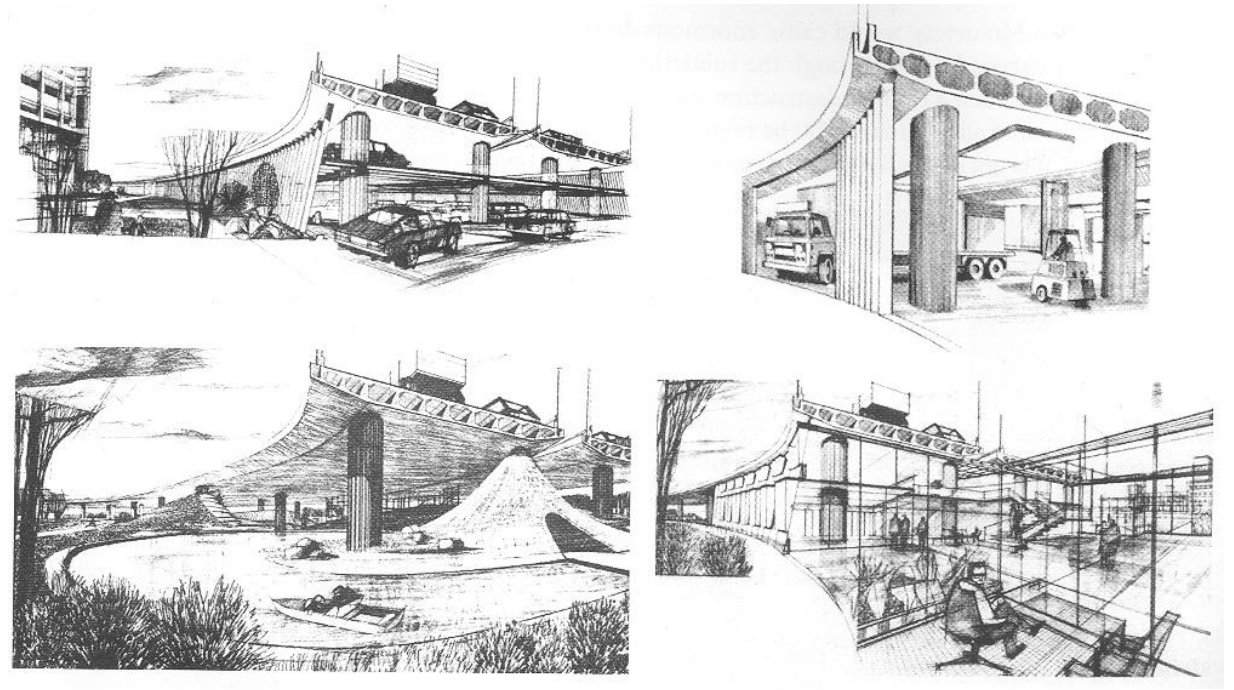

Figure 14: Sketches of Under-motorway Development

Source: Building Design Partnership 1969; Queen's University Belfast Library 1969

The graphic representation of the plan was deceiving as well. The map was designed to make the city look as simple as possible, only showing partially the existing fabric and cleverly omitting all the built areas around the new ring road (Figure 13). This is especially the case of North Street (Figure 15), where only the southern half of the street is shown, while the northern half is left grey, with apparently nothing valuable to show. The plan also includes a shopping centre adjacent to North Street, which set the ground for the subsequent construction of Castle Court. On the site of Peter's Hill there appears a large housing development that assumes the demolition of a great amount of existing streets and housing.

Much of this development was needed to deal with the low quality of housing in the area of Peter's Hill. However, the complete demolition of housing, to be replaced with new housing of questionable quality, appears far from ideal, especially for the social development of the area. In 1971, Bob Overy wrote: "The whole process of deciding what is to be built, who is to go here, how many will get back into the area, what the new community will be like, is outside the control of any organisation or group in which the people can be said in any meaningful way to participate and share responsibility. Thus irritation and anger ebb and flow round stories about the quality of building materials being used in the new houses, the design (and height) of the dwellings, the selection of people to fill the new houses" (6). Sterrett, Hackett, and Hill (2012, 52) also commented on this transformation: "Much of the new housing developed during the 1980s was designed using a ubiquitous cul-de-sac layout...in the inner city context, the layout contributed to a significant lowering of housing density." 


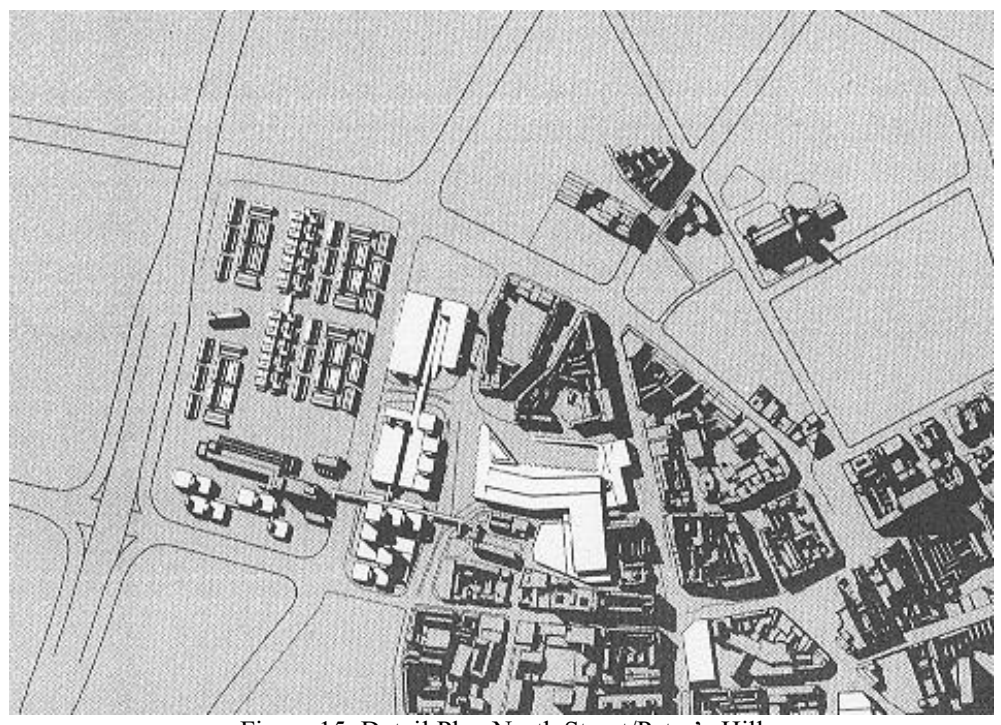

Figure 15: Detail Plan North Street/Peter's Hill

Source: Building Design Partnership 1969; Queen's University Belfast Library 1969

\section{Critique and Protest}

Internationally, a strong current of criticism of cars and roads in town planning appeared around the 1960s. Most of these comprised of journalists and architects who recognised the flaws of the new urban schemes that obliterated urban street systems. Leading them, Jane Jacobs (1961) gave sidewalks a protagonist's role in The Death and Life of Great American Cities, highlighting how streets, and not large purpose-built parks, are the best places for public life. William H. Whyte (1980), through his tireless work on urban analysis, was one of the first internationally renowned critics to closely analyse the behaviour of people in small public spaces. His study included the Street Life Project, in which he led a multidisciplinary study on the behaviour of people in streets. The Project for Public Spaces was founded in 1975 to expand on the work of Whyte. It still lobbies for the awareness of the importance of public spaces, including streets, as central to the process of place-making. In the UK, critics grew during the 1970s. John Tyme, among many others, was outraged by the reach of motorway development. He stated: "It is my belief...that the motorway/trunk road program with all its ramifications poses a consummate evil, and constitutes the greatest threat to the interest of this nation in all its history. The more roads and motorways built, the more inevitable is the decline of alternative transport modes" (Tyme 1978, 1).

Belfast was deeply affected by the complicated socio-political situation of Northern Ireland, which had deteriorated dramatically by the end of the 1960s. The civil rights movement for the rights of Catholics to housing and jobs escalated to the violence recognised worldwide as "The Troubles." The political conflict of the 1970s also established a political system that caused the city of Belfast to have a detached local government. Government responsibilities were given to organisations within "Direct Rule." The Department of the Environment, Department of Social Development, Department of Regional Development, Roads Authority, and Housing Executive were the decision makers, while the local government - the Belfast City Council — had little impact on the spatial development of the city. According to Sterrett, Hackett, and Hill (2012, 53): "Local government was reorganised in 1973 and council powers were substantially reduced. Responsibility for planning, roads, housing, regeneration and urban design rested with a range of separate central government departments, while the new local council powers were limited to what some have described as, 'burying the dead and emptying the bins."' 
Despite the complexity of the political situation, the development of the motorways did not go without opposition resulting in a public inquiry in 1972. During the legal hearings, some churches protested against the potential impact of the roads on the built environment, stating that they would prevent the reintegration of segregated communities (Cinalli 2003). Certain organisations claimed that consultants had paid insufficient attention to public transport alternatives. Among them, Sandy Row Redevelopment Association attacked every aspect of the transportation plan and secured concessions regarding the alignment of roads (Cinalli 2003). Despite the protests (Figure 16), the planners argued that there was a cost that had to be paid and that if the road did not get built the consequences would be worse (Travers Morgan 1972). Ron Wiener (1976), a critic of the motorway scheme, wrote a critical book about the new development of Belfast. He commented on the damage the motorways caused to the city and how the physical and social fabric of the city was affected by the development plans: "Without the shops, the roads lost their function as community focal points and this reduced local people's sense of identity with their area" (Wiener 1976, 58). This feeling was echoed by the press of the time: "The planners rely for their information on the generalities of survey data which cut across and frequently ignore the particular needs of people. For justification of the whole redevelopment process they use criteria of unfitness (the hallowed 'unfit for human habitation') which are extraordinarily narrow and emotion-laden" (Overy 1971, 7). The detached condition of the planning policies was criticised shortly after the decisions were made.

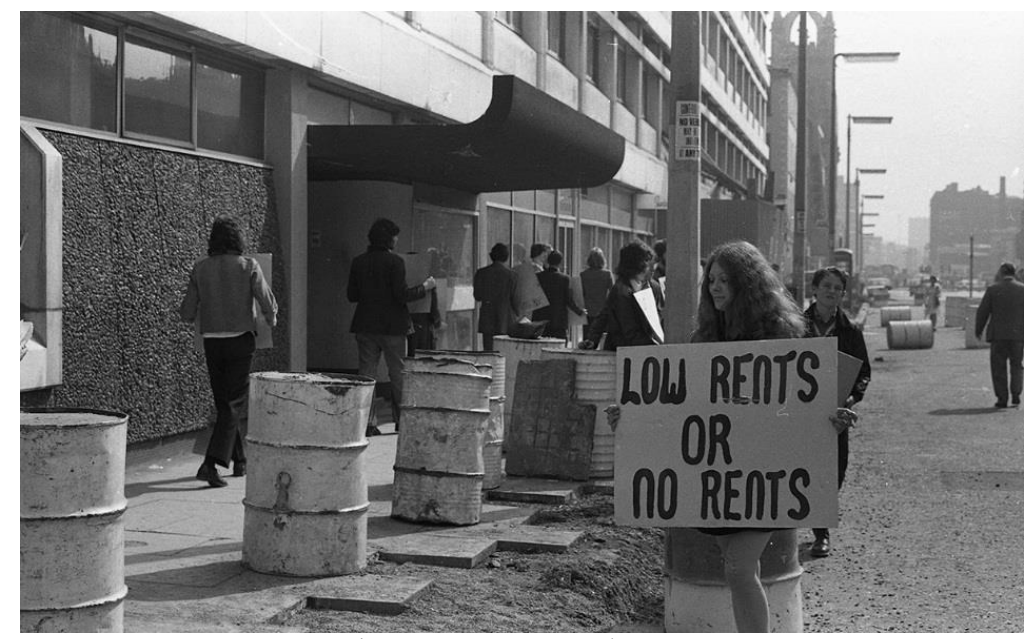

Figure 16: Protests Sandy Row

Source: The photo album of Ireland Gallery of Photography. Peter McKee Archive 1969

During the 1970s, and due to external influences such as the oil crisis and the general growing mistrust on roads solving most urban problems, the plans for the roads of Belfast slowed. After reformulation of the plans and public inquiries, the 1978 transportation strategy was written. According to Johnston (2014), the public lost faith in public inquiries due to the ineffective inquiry of 1972 and the fact that they were led by Unionists, which disregarded the opinion of the Nationalist neighbourhoods. This is not entirely true, for activism was still ongoing in 1977 when John Tyme (1978) was invited to Belfast by the Community Groups Action Committee on Transport. Tyme made harsh observations about the conditions of urban areas, but his most striking comments were on the way the Transport Plan was being managed. He stated that even though Travers Morgan might not have the wrong intentions in their development of the plan, "in each case the recommendation is for a solution requiring the building of massive road schemes" (Tyme 1978, 51), and the Committee "denies that Travers Morgan can be considered genuinely independent transport consultants, not on any improper action or intention on their part, but because their whole history and transport consultancy activity has been within 
the ambit of road construction industry" (Tyme 1978, 53). Tyme's observations did not have great repercussions in the construction of the road plans, and by 1978 the plan established the construction of the Westlink. The land around the city centre where the motorway was supposed to be built was already cleared. However, the proposed road network was smaller and narrower than that originally planned in 1969. By 1985 the Westlink, M1, M2, and M3 were finished. The construction of the roads required the demolition of housing and obliteration of communities, establishing a segregated society. In practice, the Westlink caused the demolition of the existing housing on and around Peter's Hill, and its replacement with new cul-de-sac developments. This development model was not only caused by the ethnic division of the city but also by the international phenomenon of suburbanisation that took shape in Belfast.

\section{North Street and Peter's Hill through "The Troubles"}

In the context of "The Troubles" North Street was in a vulnerable position. It was located outside the security fence that surrounded the city centre. Damage to the street was caused by a bomb on the North Street Arcade in an attack on November 6, 1971, in which eight shops were destroyed within the arcade, and on January 13, 1976, when an IRA bomb detonated prematurely inside the arcade killing two civilians and the two bombers. The arcade was subsequently abandoned until the late 1990s. However, it was not only the bombings that caused the deterioration of the fabric of North Street and Peter's Hill. The construction of the Westlink between 1978 and 1982 and the demolition of a series of buildings for parking spaces contributed more to the damage of the street than the actual bombings. On North Street in 1969 only three buildings were vacant, by 1991 of the ninety-two plots, twenty-one were vacant (Figures 17 and 18). This is a phenomenon that repeats itself in many parts of the UK, the US, and Europe, with Spiro Kostof $(1991,242)$ recognising that "car traffic has become the central, most unavoidable experience of the public realm." Within this international phenomenon, Belfast is indeed recognised as one of the most car-dependent (Smyth 2006) medium-sized cities in Western Europe (Northern Ireland Statistics and Research Agency 2008).

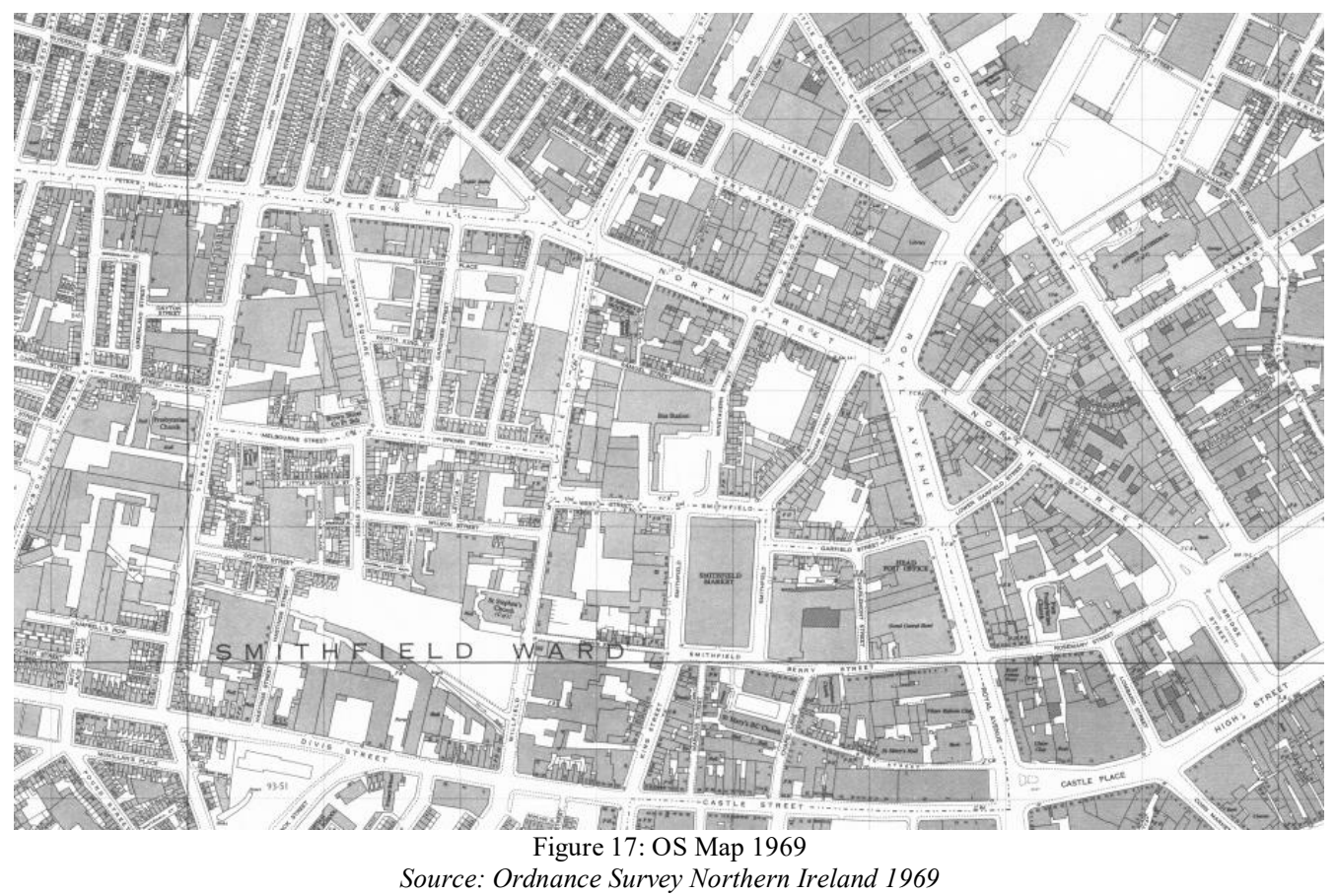




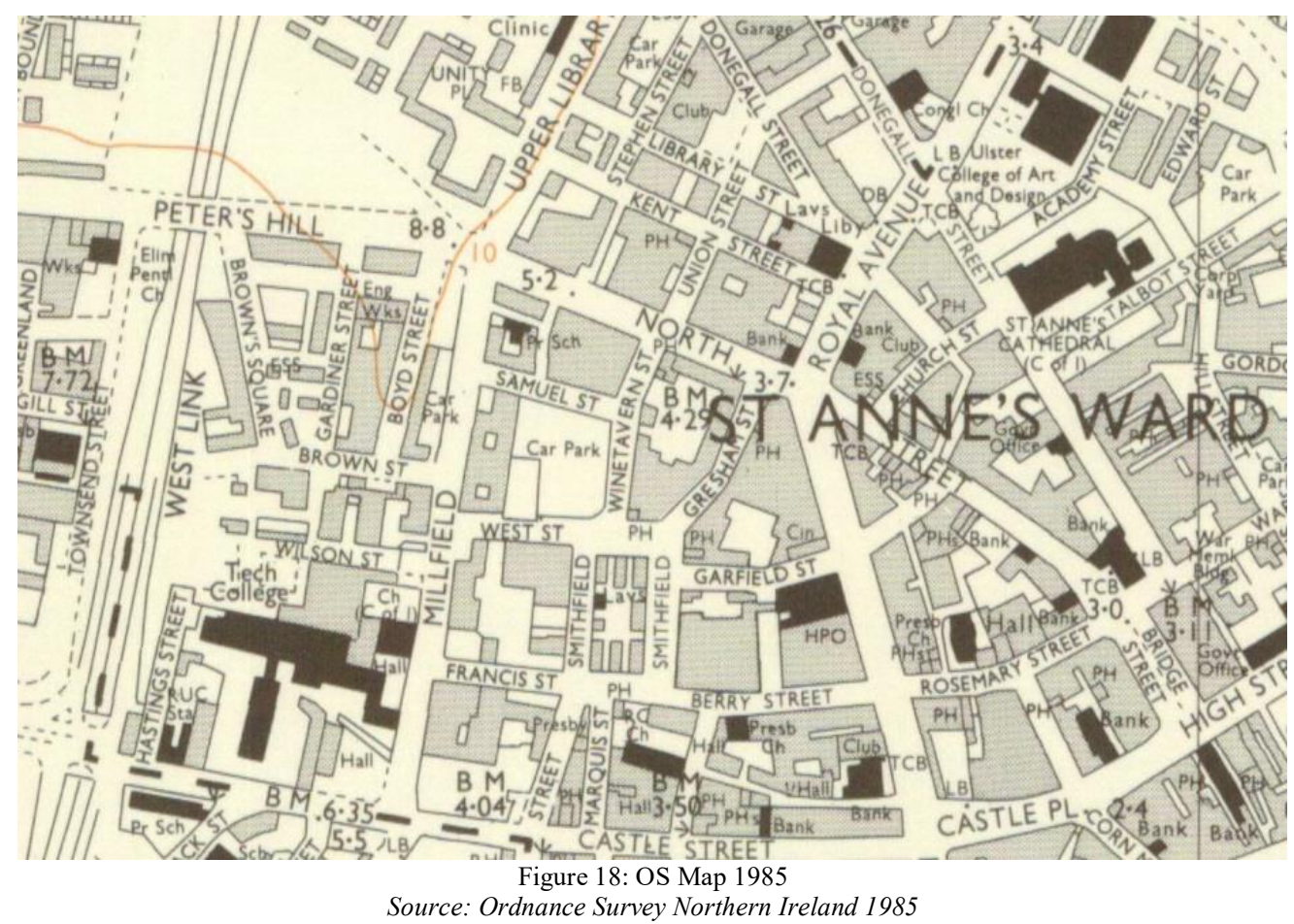

Peter's Hill suffered a much more radical transformation to its built fabric. Practically all the housing fabric of the nineteenth century was demolished for the development of the motorway and new housing (Figure 18). The baths, public houses, and housing that had been the built fabric of the street for more than one hundred years, and were still in use in 1969, were all demolished and replaced with a combination of road networks and cul-de-sac housing that was planned and built throughout the 1980s. North Street was deeply affected by the planning tendencies of the 1980s.

\section{North Street/Peter's Hill 1980-2016}

Since the late 1980s a series of large-scale retail developments transformed the fabric of the city. Steps away from North Street, Castlecourt shopping centre on Royal Avenue was built in 1988 (Figure 19) after the demolition of the Grand Central Hotel and the Post Office. Three streets were built over to allow the construction of the shopping centre: Garfield Street, Berry Street, and the Smithfield Market. This building, therefore, blocked the way to West Belfast from the city centre. The shopping centre still has a major presence in the urban landscape of Royal Avenue. 


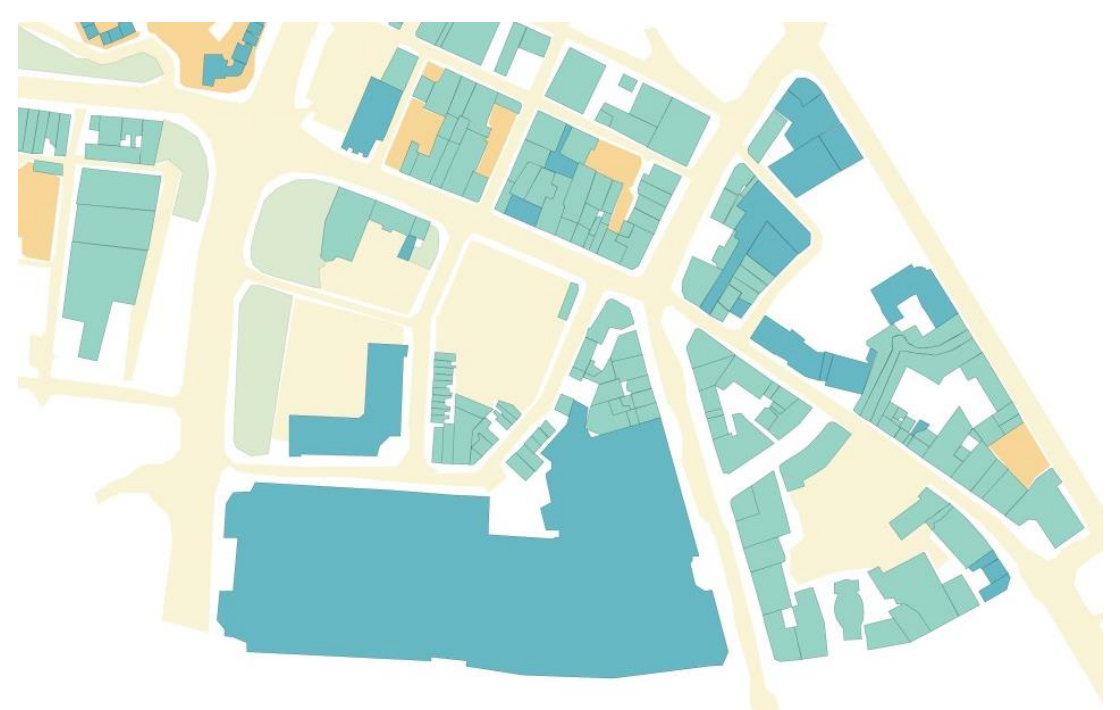

Figure 19: Castlecourt. Map Detail 2016

Source: Author: Agustina Martire. Base Map: OS Map. Ordnance Survey 2005

After a couple of decades of peace in Northern Ireland, some areas of Belfast City Centre have experienced a revival; the Cathedral Quarter has, since the late 2000s, seen the rise of cafes, concert halls, bars, hotels, and restaurants that have boosted the vibrancy of its streets night and day. However, even though North Street is immediately adjacent to the Cathedral Quarter, it has not seen such development, falling into a relative decline. Five buildings on a site owned by CastleCourt on Upper North Street were demolished in 2006 (Figure 19) to give way for a second parking lot on North Street. A series of significant historic buildings lay vacant. These include the former Waring Street assembly rooms, a 1769 construction that was arguably Belfast's most important building at one time, the lower Garfield street building (60 North street, 1898), and the North street arcade (the only example of a 1930s shopping arcade in Northern Ireland). Most recently, three significant but unlisted buildings were demolished in December 2016 (Figure 20). Terri Hooley, a prominent Belfast music manager praised what North Street had previously been: "North Street was absolutely fabulous. It looked very bright, very inviting, very busy. When you look at it now, North Street is an absolute disgrace, it looks like a shanty town" (Simpson 2014, 1).

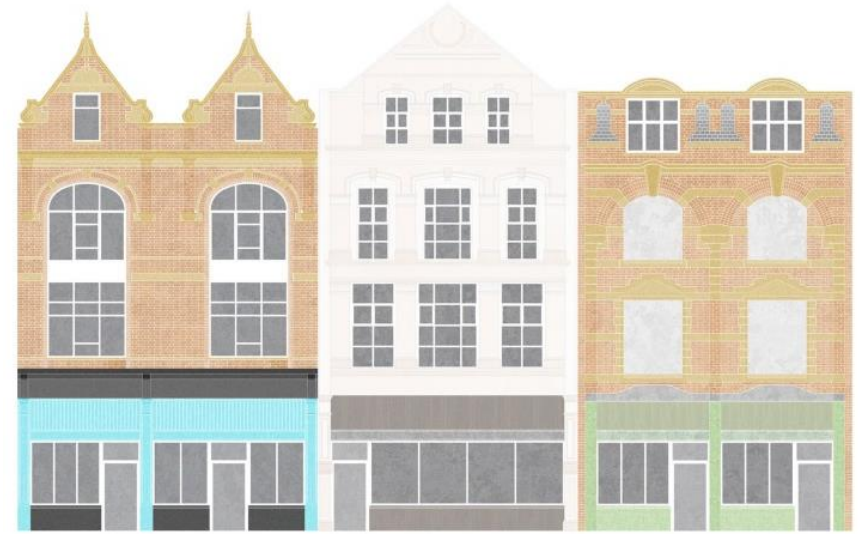

Figure 20: Heritage on North Street

Source: Callum Black. MArch. Queen's University Belfast 2016 
Despite the vacant buildings and parking lots, the buildings that are occupied cater to a variety of communities. A study carried out by Masters in Architecture students at Queen's University Belfast revealed multi-layered uses of North Street that are not easily discernible in a brief visit. Cafes, restaurants, and galleries cater to young and old populations, locals and immigrants, and students and professionals. Bookstores, tattoo shops, barbers, and hairdressers continue to survive in a vibrant context. Some shops have been part of the street for more than 100 years. Products from all over the world are sold in non-franchised independent shops, including food, furniture, toys, and comics (Figure 21). However, unfortunately, these lively building fronts cohabit among a large series of abandoned, highly valuable heritage buildings and parking lots that cater only to commuters. A series of urban plans have been discussed and approved in recent years for the regeneration of the area. The Royal Exchange Plan was approved in 2012 and threatens the existence of many of these businesses proposing a "mixed use" plan to regenerate the area. This plan is focused on commercial occupation and housing, proposing yet another unnecessary large shopping mall for the city centre. If Belfast continues to encourage this type of city centre development much of the liveability and vibrancy of North Street would be lost, while its potential for greater diversity would completely disappear.

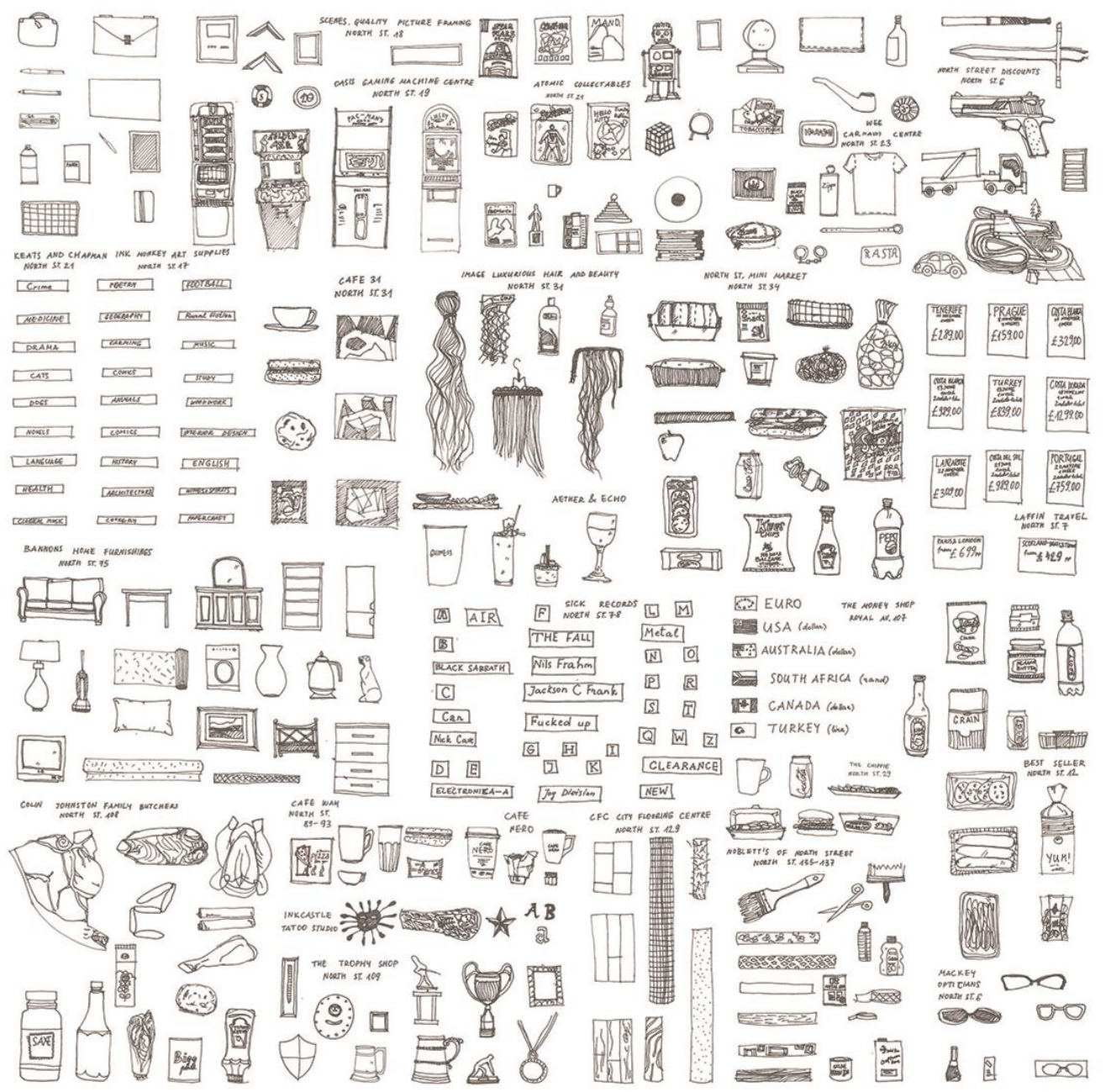

Figure 21: Variety of Products Sold in North Street Source: Milde Paceviciute. MArch. Queen's University Belfast 2016 


\section{Conclusions: Streets not Roads}

In the last few decades, activists, artists, designers, and scholars have raised awareness of the need to make streets more liveable and reduce car use in city centres. Urban design firms have in turn proposed solutions to the design and management of traffic to improve streets for pedestrians (Dover and Massengale 2014; Jacobs 1995; Moughtin and Mertens 1992; Poulton 1982). Many cities in the world have responded to this need with varying results for the urban landscape and its inhabitants. Recently, San Francisco, Seoul, Portland, Rio de Janeiro (Walker 2016), and Sao Paulo have gone through the titanic task of demolishing motorways to clear space for a more inclusive city. Madrid's riverside motorway has been replaced by a miles-long strip park that now caters to millions of users. However, many other cities have failed to put such changes into practice. UK cities appear as the most car-dependent in Europe (Campaign for Better Transport 2011). According to the theory of induced demand, ${ }^{5}$ the constant widening of roads provokes the greater use of the car as means of transportation. This idea has been used widely in the fight against the building and widening of roads internationally. Despite some critique to the development of roads in Belfast, Johnston (2014) repeatedly justifies advocacy by stating that people are inherently car dependent. This has been proven not to be the case, through studies on car dependency (Mattioli 2013; Wickham and Lohan 1999; Kenworthy and Laube 1999). There is a general understanding now that the car is detrimental to the environment and increasingly to the health of drivers and passengers. In the case of the aging population, it is believed that car dependency increases isolation (Buys et al. 2012). A closer look at case studies shows that inner-city areas, both for convenience and economic reasons, have a very low car ownership. Those who benefit from the roads tend to be those living in the suburbs, creating a misbalanced supply of infrastructure for those living in inner-city areas. With Belfast as an example, it is clear that in 2011, car ownership in the inner city was less than 24 percent, while in the suburbs it was more than 80 percent. There is a similar argument in terms of parking; the more cheap and accessible parking a city provides in its centre, the more people will choose to drive to town and avoid public transport.

Urban designers and architects have also responded to this renewed value of streets for pedestrians. Streets were considered as "human movement institutionalised" by Joseph Rykwert $(1978,15)$, in which movement is perceived as central to streets as public spaces. Allan B. Jacobs, urban designer and researcher, expressed in 1995 that "streets are more than public utilities, more than the equivalent of water lines and sewers and electrical cables; more than linear physical spaces that permit people and goods to get from here to there" (3). Streets, as opposed to roads, do not have a simple precise technical function but a greatly diverse set of forms and meanings that cannot be limited to the purely functional. Moreover, Jan Gehl (1989, 17) stated that "the street is the largest stage in the city, and the most used." Then the street acts as a space of performance of everyday life, very different from roads, where the only exchange is that between individuals from inside their cars. Accordingly, James Howard Kunstler (1994, 131), American urban critic, writes that "the road is now like the television, violent and tawdry. The landscape it runs through is littered with cartoon buildings and commercial messages. There is little sense of having arrived anywhere, because every place looks like no place in particular." This impression of the road is inherent to the American landscape, but a similar thing could be said about roads in other parts of the world, especially those where sprawl has developed uncontrollably. Since the 1960 s, there has been a significant amount of criticism levelled at road development and a growing awareness that streets and street systems provide better living

\footnotetext{
5 "Induced-demand effect: increases in highway capacity attract new traffic" (Downs 1962, 393). Rebound effect: "The term was first applied narrowly to the direct increase in demand for an energy service whose supply had increased as a result of improvements in technical efficiency in the use of energy. Since then, the rebound has been more broadly construed to include wider economic effects" (Greening, Greene, and Difiglio 2000, 390).
} 
environments than roads. But this is not a simple problem to address, and especially not one with simple solutions.

As mentioned earlier, Belfast has not given a deserved value to its streets. The mere space given to cars currently on North Street and Peter's Hill is enough to raise the question of the use of urban space and its significance. These images (Figures 22 and 23) should be enough for local authorities to at least question whether this is the best use of public space in city streets.

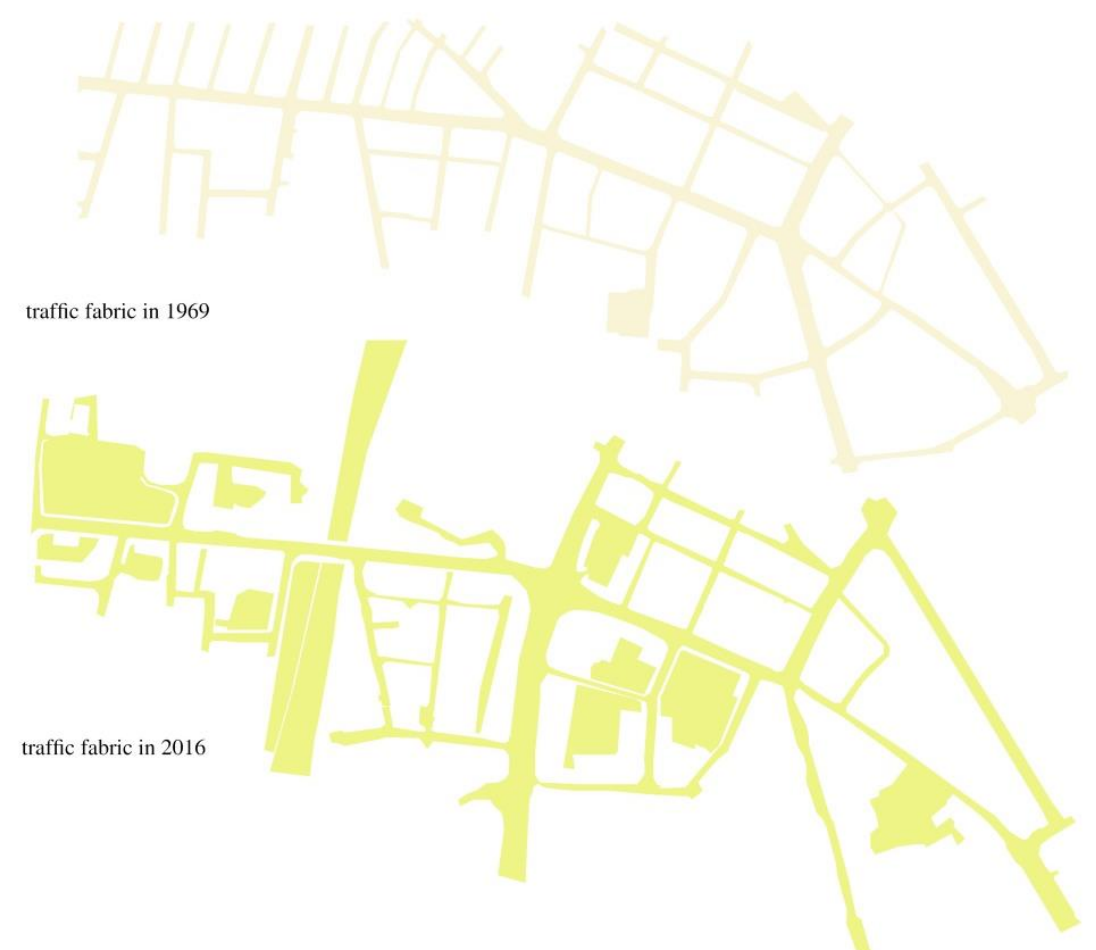

Figure 22: Traffic Fabric Belfast 1969 and 2016

Source: Author: Agustina Martire; Base Map: OS Map; Ordnance Survey 2005 and Google Maps 


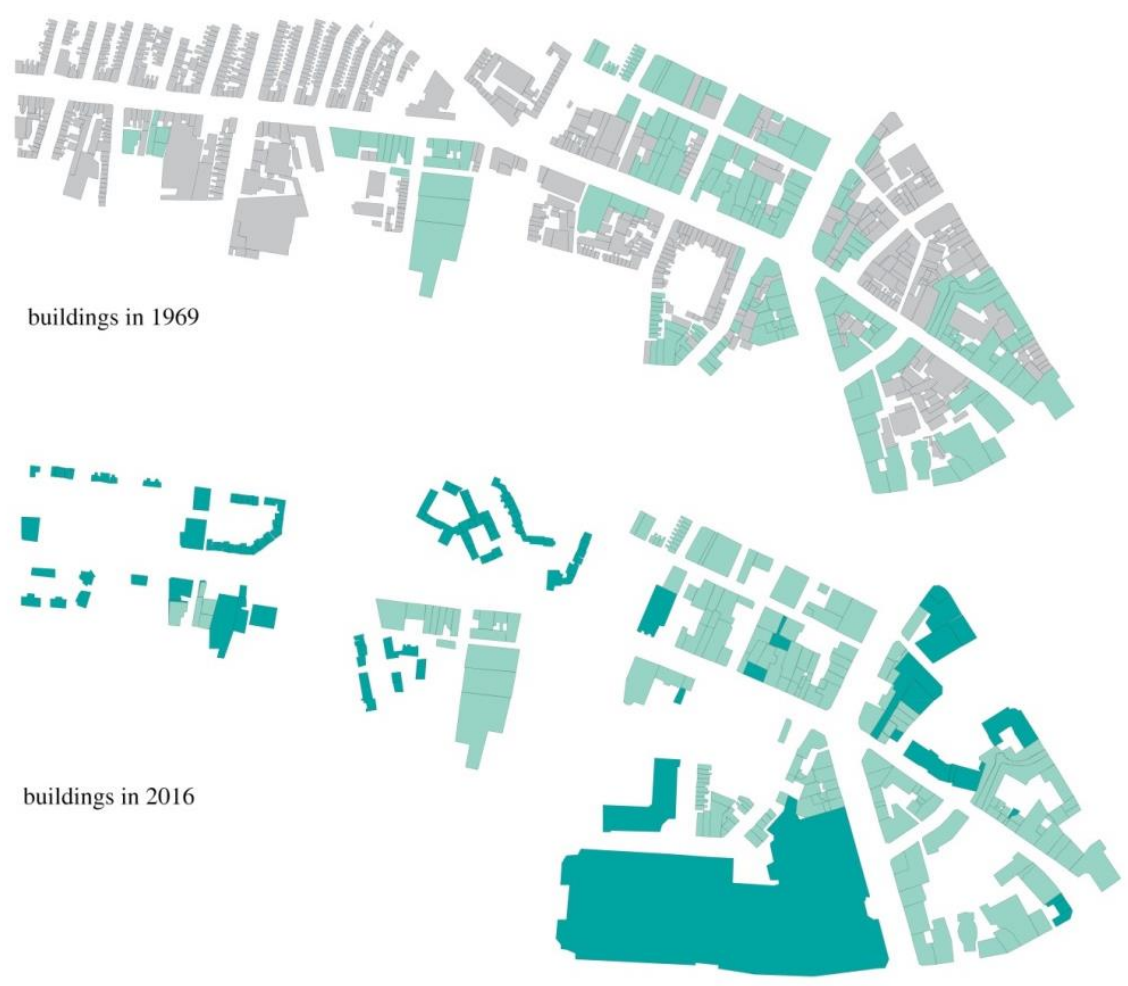

Figure 23: Figure Ground Comparison of Built Fabric 1969-2016 Source: Ordnance Survey Northern Ireland 2016

Between the motorway plans of the 1960s, political turmoil of the 1970s, suburbanisation of the 1980s, and large retail development since the 1990s, the streets of Belfast City Centre have suffered relentless erasure and demolition, closure of local retail, and hollowing out of existing buildings. These projects have not received consistent criticism, with their construction remaining largely unchallenged. Only two established organisations have voiced informed questions about large retail and road development: PLACE, the centre for Planning Landscape Architecture Community Environment in Belfast (2011-today) and FAB, Forum for an Alternative Belfast (2009-2015). Both organisations are not-for-profit and have been actively organising events to raise awareness of the significance of these planning decisions for the quality of life of Belfast inhabitants. Belfast's planning powers since the late 1960s were scattered through different authorities such as the Department of the Environment, Department of Social Development, Department of Regional Development, Roads Authority, and Housing Executive. This system did not allow for a coherent management of public spaces, especially streets. The system of planning recently changed in Northern Ireland in April 2015 with the devolution of planning powers to the city council. This is a major opportunity for change, but the city council needs the tools to be able to transform the development of the city centre.

The destruction of the urban landscape to give space to roads and motorised movement is under scrutiny internationally, but alternative proposals are only beginning to be developed. There are cases of repairing and re-stitching the urban fabric, but these are isolated, and even though we can learn from them, further research is needed. In this context, the project StreetSpace is aiming to redefine the way that streets are analysed as public spaces. After a series of workshops to describe the physical qualities of streets in both plan and section, it was evident that architecture does not have enough tools to properly understand streets as public spaces. 
Therefore, a new set of questions are being addressed by members of the project from disciplines as diverse as architecture, planning, history, geography, sociology, sound, film, and art. How do we analyse street space? How do we communicate this analysis? How can we use these methods to change/improve street spaces? Only by posing these questions and joining policy makers, scholars, artists, and users of streets will we be able to provide streets that are inclusive and active, lively and vibrant.

\section{REFERENCES}

Bajunid, Anniz Fazli Ibrahim, Mohamed Yusoff Abbas, and Abdul Hadi Nawawi. 2013. “Assessing Cul-de-sac Neighbourhoods: A Methodological Prelude." Procedia-Social and Behavioural Sciences 84 (9): 288-92.

BBC News. 2015. "Belfast Royal Exchange: Uncertainty over Regeneration Scheme." $B B C$ News, November 19. http://www.bbc.co.uk/news/uk-northern-ireland-34867672.

Benn, George. 1823. The History of the Town of Belfast, with an Accurate Account of Its Former and Present State: To which are Added a Statistical Survey of the Parish of Belfast and a Description of Some Remarkable Antiquities in its Neighbourhood. Belfast: A. Mackay Jr.

Boal, Frederick W. 1994. "Belfast: A City on Edge." In Europe's Cities in the Late Twentieth Century, edited by H. Clout, 102-16. Amsterdam: Royal Dutch Geographical Society.

Boal, Fredrick W., and J. Neville H. Douglas, eds. 1982. Integration and Division: Geographical Perspectives on the Northern Ireland Problem. London: Academic Press.

Bollens, Scott A. 2000. On Narrow Ground: Urban Policy and Ethnic Conflict in Jerusalem and Belfast. Albany: State University of New York Press.

Bridge, Albert. 2010. "Lower North Street." Geograph. Accessed August 19, 2016. http://www.geograph.org.uk/snippet/3737.

Buchanan, Colin. 1963. Traffic in Towns: A Study of the Long Term Problem of Traffic in Urban Areas. London: Her Majesty's Stationary Office.

Building Design Partnership. 1967. Belfast Urban Area Interim Planning Policy. Belfast: Building Design Partnership in association with N. Lichfield and Associates, D. Lovejoy and Associates, and John Madge.

1969. Report on Belfast Corporation on Planning Policy in the City Centre. Belfast: Building Design Partnership in association with N. Lichfield and Associates, D. Lovejoy and Associates and John Madge.

Burnham, Daniel, and Edward Bennett. 1909. The Plan of Chicago. Chicago: Princeton Architectural Press.

Burton, Elizabeth, and Lynne Mitchell. 2006. Inclusive Urban Design: Streets for Life. Oxford: Architectural Press.

Buys, Laurie, Stephen Snows, Kimberly van Megen, and Evonne Miller. 2012. "Transportation Behaviours of Older Adults: An Investigation into Car Dependency in Urban Australia." Australasian Journal on Ageing 31: 181-86.

Campaign for Better Transport. 2011. Car Dependency Scorecard 2011. London. Accessed June 25, 2016. http://www.bettertransport.org.uk/sites/default/files/research-files/european -car-dependency-scorecard-2011.pdf.

Campbell, Gavin. 2016. "North Street and Hill Street, A Tale of Two Streets." MArch dissertation. Queen's University Belfast. 
Cinalli, Manlio. 2003. "Socio-politically Polarized Contexts and Urban Mobilization: A Study of Two Campaigns of Protest in Northern Ireland." The International Journal for Urban and Regional Research 27 (1): 158-77.

Collins, George, and Christiane Crassemann Collins. 1986. Camillo Sitte, The Birth of Modern City Planning. New York: Dover, Rizzoli.

Connolly, Sean. 2012. Belfast 400: People, Place and History. Liverpool: Liverpool University Press.

Conzen, M. R. G. 1960. "Alnwick, Northumberland: A Study in Town-plan Analysis." Transactions and Papers (Institute of British Geographers) 27: iii $+\mathrm{ix}-\mathrm{xi}+1+3-122$.

Cozens, Paul, and David Hillier. 2008. "The Shape of Things to Come: New Urbanism, the Grid and the Cul-de-sac." International Planning Studies 13 (1): 51-73.

Dover, Victor, and John Massengale. 2014. Street Design: The Secret to Great Cities and Towns. New Jersey: Wiley.

Downs, Anthony. 1962. "The Law of Peak-hour Expressway Congestion." Traffic Quarterly 16 (3): 393-409.

Ellis, Geraint, and Stephen McKay. 2000. "City Management Profile: Belfast." Cities 17 (1): $47-$ 54.

Ellis, Geraint, Brendan Murtagh, and Andrew Grounds. 2015. "City of Dreams? Belfast, Planning and the 'Myth' of Development." Paper presented at 47th Conference of Irish Geographers. Belfast, UK.

Evans, Estyn, and Emrys Jones. 1955. "The Growth of Belfast." The Town Planning Review 26 (2): $92-111$.

Forum for Alternative Belfast. 2009. Missing City Map. Belfast: Belfast Conflict Resolution Consortium.

Ford, Larry. 2000. The Spaces between Buildings. Baltimore: Johns Hopkins University Press.

Gaffikin, Frank, and Mike Morrissey. 2011. "Community Cohesion and Social Inclusion: Unravelling a Complex Relationship." Urban Studies 48 (6): 1089-118.

Gehl, Jan. 2010. Cities for People. Washington, DC: Island Press. 1989. “A Changing Street Life in a Changing Society." Places Journal 6 (1): 8-17.

Greening, Lorna A., David L. Greene, and Carmen Difiglio. 2000. "Energy Efficiency and Consumption: The Rebound Effect. A Survey." Energy Policy 28 (6/7): 389-401.

Hebbert, Michael. 1999. "A City in Good Shape: Town Planning and Public Health." The Town Planning Review 7 (4): 433-53.

H.M.S.O. 1945. "Planning Proposals for the Belfast Area, Interim Report of the Planning Commission, London." Architects' Journal: 331-34.

Hochschild, Thomas. 2014. "The Cul-de-sac Effect: Relationship between Street Design and Residential Social Cohesion.” Journal of Urban Planning and Development 141 (1): 16.

Jacobs, Allan B. 1995. Great Streets. Cambridge, Mass: MIT Press.

Jacobs, Jane. 1961. The Death and Life of Great American Cities. New York: Modern Library.

Johnston, Wesley. 2014. The Belfast Urban Motorway: Engineering, Ambition and Social Conflict. Belfast: Colourpoint Books.

Kenworthy, Jeffrey R., and Felix B. Laube. 1999. "Patterns of Automobile Dependence in Cities: An International Overview of Key Physical and Economic Dimensions with Some Implications for Urban Policy." Transportation Research Part A 33: 691-723.

Kostof, Spiro. 1991. The City Shaped: Urban Patterns and Meanings through History. London: Thames and Hudson.

1992. The City Assembled: The Elements of Urban Form through History. London: Thames and Hudson.

Kunstler, James Howard. 1994. Geography of Nowhere: The Rise and Decline of America's Man-Made Landscape. New York: Simon and Schuster. 
2004. "James Howard Kunstler: The Ghastly Tragedy of Suburbs" (video file). Accessed June 19, 2015. https://www.ted.com/talks/james_howard_kunstler.

Le Corbusier. 1929. The City of To-morrow and Its Planning. New York: Dover.

Lucy, William, and David Phillips. 2006. Tomorrow's Cities, Tomorrow's Suburbs. Chicago, IL: Planners Press.

Mantho, Robert. 2015. The Urban Section. An Analytical Tool for Cities and Streets. Oxon and New York: Routledge.

Mattioli, Giulio. 2013. "Car Dependence, Sustainability and the Transport Policy Stalemate: The Potential Trade-offs between Intra- and Inter-generational Equity." The International Journal of Sustainability Policy and Practice 8 (1): 45-57.

Matthew, Robert Hogg. 1963. Belfast Regional Survey and Plan: Recommendations and Conclusions: Presented to Parliament by Command of His Excellency the Governor of Northern Ireland. 451. Belfast: H.M.S.O.

Moughtin, Cliff, and Miguel Mertens. 1992. Urban Design, Street and Square. Oxford: Elsevier.

Murtagh, Brendan. 1999. "Urban Segregation and Community Initiatives in Northern Ireland." Community Development Journal 34 (3): 219-26.

Northern Ireland Statistics and Research Agency. 2008. Travel Survey for Northern Ireland 2006-2008. Belfast: Department for Regional Development.

Overy, Bob. 1971. "Redevelopment in Belfast." Fortnight 19 (11): 6-8.

Porta, Sergio, and Ombretta Romice. 2010. "Plot Based Urbanism: Towards Time-consciousness in Place-making." Working paper. University of Strathclyde, Glasgow.

Poulton, Michael C. 1982. "The Best Pattern of Residential Streets." Journal of the American Planning Association 48 (4): 466-80. doi:10.1080/01944368208976818.

Project for Public Spaces. Accessed October 23, 2015. http://www.pps.org.

Rudofsky, Bernard. 1982. Streets for People: A Primer for Americans. New York: Van Nostrand Reinhold.

Rykwert, Joseph. 1978. "The Street: The Use of its History.” In On Streets, edited by Stanford Anderson, 15-27. Cambridge, Mass: MIT Press.

Simpson, J. E. R. 2014. "After the Fire: North Street Arcade Ten Years On." BBC Northern Ireland, May 15. http://www.bbc.co.uk/news/uk-northern-ireland-27397632.

Smyth, A. 2006. "Belfast: Return to Motown." In Enduring City, Belfast in the Twentieth Century, edited by F. Boal and S. Royle, 99-21. Belfast: Blackstaff.

Southworth, Michael, and Eran Ben-Joseph. 2003. Streets and the Shaping of Towns and Cities. Washington, DC: Island Press.

Sterrett, Ken, Mark Hackett, and Declan Hill. 2012. "The Social Consequences of Broken Urban Structures: A Case Study of Belfast." Journal of Transport Geography 21: 49-61.

Stewart, Linda. 2014. "This Dilapidated Street in the Heart of Belfast has been an Eyesore for 10 Years." The Belfast Telegraph, January 28.

Travers Morgan, R. 1972. "Belfast Transportation Plan Public Inquiry. General Dossier No5: Implications of Doing Nothing." February, 1972.

Tyme, John. 1978. Motorways versus Democracy. Public Inquiries into Road Proposals and Their Political Significance. London and Basingstoke: Springer.

Vance, James E. 1990. The Continuing City: Urban Morphology in Western Civilization. Baltimore: Johns Hopkins University Press.

Vernez Moudon, Anne. 1987. Public Streets for Public Use. New York: Columbia University Press.

Walker, Alissa. 2016. "Six Freeway Removals That Changed Their Cities Forever." Gizmodo, May 25. http://gizmodo.com/6-freeway-removals-that-changed-their-cities-forever $-1548314937$.

Whyte, William H. 1980. The Social Life of Small Urban Spaces. Project for Public Spaces. New York: Conservation Foundation. 
Whitehand, J. W. R. 1987. "M. R. G. Conzen and the Intellectual Parentage of Urban Morphology." Planning History Bulletin 9: 35-41.

Wiener, Ron. 1976. The Rape and Plunder of the Shankill in Belfast: People and Planning. Belfast: Nothems Press.

Wickham, James, and Maria Lohan. 1999. "The Transport Rich and the Transport Poor: Car Dependency and Social Class in Four European Cities." Conference Paper presented at the Urbanism and Suburbanism at the End of the Century Conference at National University of Ireland, Maynooth, Ireland, November 1999.

Zhang, Ming. 2013. "On the Cul-de-sac vs. Checker-board Street Network: Search for Sustainable Urban Form." International Review for Spatial Planning and Sustainable Development 1 (1): 116.

\begin{abstract}
ABOUT THE AUTHOR
Agustina Martire: Lecturer, Architecture, School of Natural and Built Environment, Queen's University Belfast, UK
\end{abstract}




\section{Spaces and Flows: An International Journal of}

Urban and ExtraUrban Studies addresses some of the most pressing and perturbing social, cultural, economic and environmental questions of our times, focusing on spaces and flows as crucibles and vectors of ongoing transformation.

The journal discusses several central questions: What are the new and emerging spaces of production, consumption, and human living as communities, regions, and societies organize and re-organize in contemporary times? And what are the new flows of people, goods, services, information, and ideas? How are they being constructed and how are they functioning?
The issues addressed in the journal oscillate between the local and the global, the empirical and the theoretical, the utopian and the pragmatic, the disciplinary and the transdisciplinary, research and its application, and the practices of knowledge making and those of knowledge dissemination.

In addition to traditional scholarly papers, this journal invites case studies that take the form of presentations of practice-including documentation of spatial practices and exegeses analyzing the effects of those practices.

Spaces and Flows: An International Journal of Urban and ExtraUrban Studies is a peer-reviewed scholarly journal. 